Prepared in cooperation with Mount Pleasant Waterworks

\title{
Simulation of Reclaimed-Water Injection and Pumping Scenarios and Particle-Tracking Analysis near Mount Pleasant, South Carolina
}

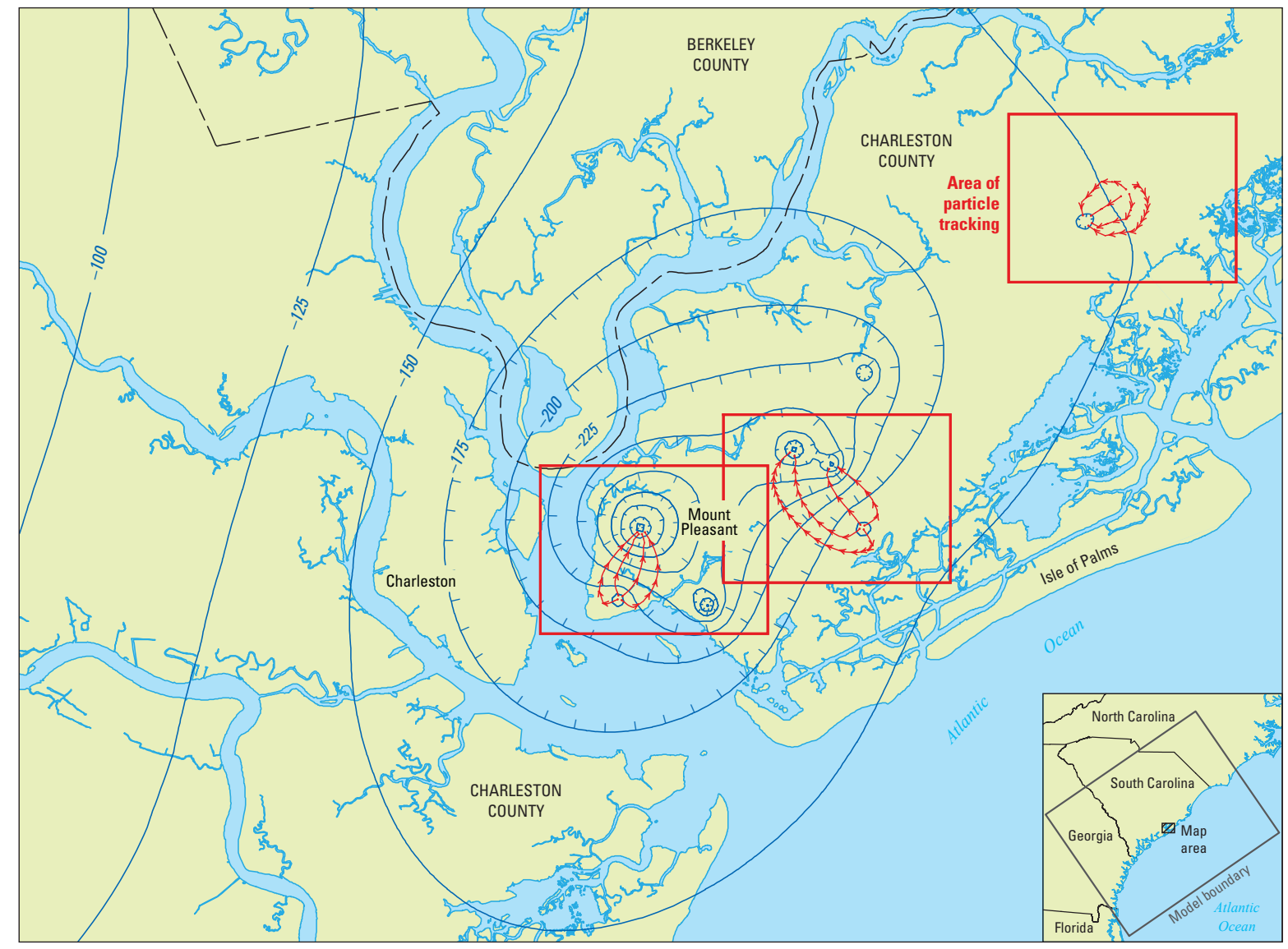

Scientific Investigations Report 2009-5185 
Cover. Image compiled from report illustrations. 


\section{Simulation of Reclaimed-Water Injection and Pumping Scenarios and Particle- Tracking Analysis near Mount Pleasant, South Carolina}

By Matthew D. Petkewich and Bruce G. Campbell

Prepared in cooperation with Mount Pleasant Waterworks

Scientific Investigations Report 2009-5185 


\title{
U.S. Department of the Interior \\ KEN SALAZAR, Secretary
}

\author{
U.S. Geological Survey \\ Suzette M. Kimball, Acting Director
}

\section{U.S. Geological Survey, Reston, Virginia: 2009}

\begin{abstract}
For more information on the USGS - the Federal source for science about the Earth, its natural and living resources, natural hazards, and the environment, visit http://www.usgs.gov or call 1-888-ASK-USGS

For an overview of USGS information products, including maps, imagery, and publications, visit http://www.usgs.gov/pubprod

To order this and other USGS information products, visit http://store.usgs.gov
\end{abstract}

Any use of trade, product, or firm names is for descriptive purposes only and does not imply endorsement by the U.S. Government.

Although this report is in the public domain, permission must be secured from the individual copyright owners to reproduce any copyrighted materials contained within this report.

Suggested citation:

Petkewich, M.D., and Campbell, B.G., 2009, Simulation of reclaimed-water injection and pumping scenarios and particle-tracking analysis near Mount Pleasant, South Carolina: U.S. Geological Survey Scientific Investigations Report 2009-5185, 41 p. 


\section{Contents}

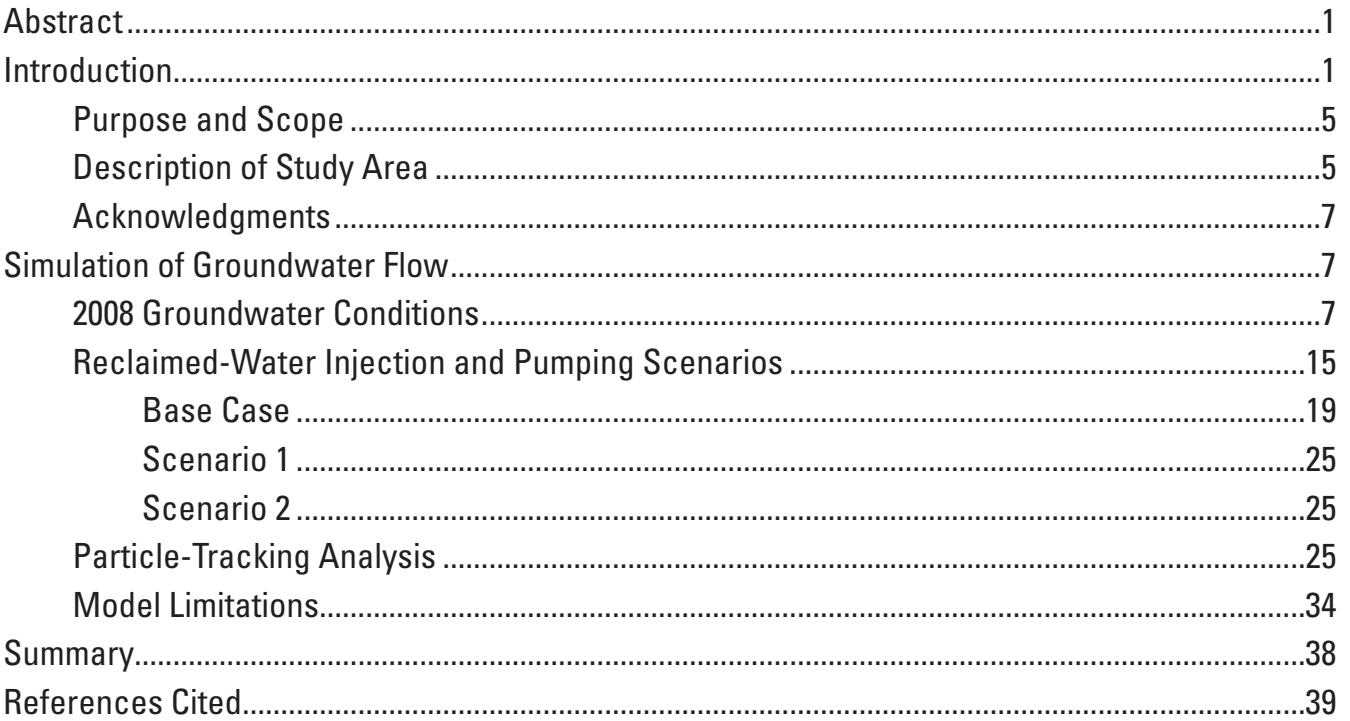

\section{Figures}

1. Map showing location of study area and model boundary, Mount Pleasant, South Carolina

2. Map showing the potentiometric surface of the Middendorf aquifer in South Carolina, November 2004

3. Hydrographs of BRK-431 observation well near Moncks Corner, South Carolina, and $\mathrm{CHN}-14$ observation well in Charleston, South Carolina, and pumping from wells in Mount Pleasant, South Carolina..

4. Schematic diagram showing hydrogeologic framework, model layers, and boundary conditions across the South Carolina Coastal Plain.

5. Map showing existing production wells in the Middendorf aquifer, potential injection wells, area of water-budget analysis, and areas of particle-tracking analysis near Mount Pleasant, South Carolina

6. Graph showing groundwater use from the Middendorf aquifer in Charleston, Berkeley, and Dorchester Counties, South Carolina, 1990-2008.

7. Graphs showing measured and simulated groundwater altitudes for observation wells CHN-14 in Charleston, South Carolina, and BRK-431 near Moncks Corner, South Carolina

8-12. Maps showing-

8. Horizontal hydraulic conductivity pilot points that were adjusted during recalibration of the Mount Pleasant, South Carolina, model

9. Simulated 2004 potentiometric surface for the Middendorf aquifer near Mount Pleasant, South Carolina, for the recalibrated model.

10. Groundwater-level differences between the original model and the recalibrated model for the 2004 Middendorf aquifer potentiometric surface near Mount Pleasant, South Carolina

11. Simulated 2050 potentiometric surface of the Middendorf aquifer near Mount Pleasant, South Carolina, for the Base Case simulation. 
12. Simulated groundwater-level change between 2004 and 2050 in the Middendorf aquifer in the Mount Pleasant study area using the Base Case simulation.

13. Simulated hydrographs from 1985 to 2050 for CHN-14, BRK- 431, and an imaginary well for three model scenarios......

14. Simulated water budget for 2011 for Base Case, Scenario 1, and Scenario 2................23

15. Simulated water budget for 2050 for Base Case, Scenario 1, and Scenario 2................24

16-21. Maps showing -

16. Simulated 2050 potentiometric surface of the Middendorf aquifer near Mount Pleasant, South Carolina, for Scenario 1.

17. Simulated 2050 water-level difference between the Base Case and Scenario 1 for the Middendorf aquifer near Mount Pleasant, South Carolina...

18. Simulated 2050 potentiometric surface of the Middendorf aquifer near Mount Pleasant, South Carolina, for Scenario 2.

19. Simulated 2050 water-level difference between the Base Case and Scenario 2 for the Middendorf aquifer near Mount Pleasant, South Carolina...

20. Simulated 2050 potentiometric surface maps of the Middendorf aquifer near Mount Pleasant, South Carolina, and particle-tracking results using a 20-percent porosity for Scenario 2 for particles released at proposed injection wells 1,2 , and 3 .

21. Simulated 2050 potentiometric surface maps of the Middendorf aquifer near Mount Pleasant, South Carolina, and particle-tracking results using a 30-percent porosity for Scenario 2 for particles released at proposed injection wells 1,2 , and 3 .

\section{Tables}

1. Ranges of reported aquifer transmissivity, storage coefficient, calculated horizontal hydraulic conductivity, and simulated horizontal hydraulic conductivity for the aquifers in the study area.

2. Changes made to the Middendorf aquifer specific storage and horizontal hydraulic conductivity pilot-point values during recalibration of the Mount Pleasant, South Carolina, model

3. Simulated pumping rates for production wells in the Mount Pleasant, South Carolina, area for the Base Case simulation

4. Simulated pumping and injection rates for wells in the Mount Pleasant, South Carolina, area for Scenario 1

5. Simulated pumping and injection rates for wells in the Mount Pleasant, South Carolina, area for Scenario 2

6. Simulated 2050 groundwater altitudes and difference between Base Case and two scenarios in the Middendorf aquifer for the Mount Pleasant, South Carolina, area......19

7. Summary of simulated times of travel for Scenario 2 for conditions of two porosities and distances between injection wells and nearest downgradient production well, Mount Pleasant area model, South Carolina 


\section{Conversion Factors, Datums, Definitions, and Abbreviations and Acronyms}

Inch/Pound to SI

\begin{tabular}{|c|c|c|}
\hline Multiply & By & To obtain \\
\hline \multicolumn{3}{|c|}{ Length } \\
\hline inch (in.) & 2.54 & centimeter $(\mathrm{cm})$ \\
\hline foot $(\mathrm{ft})$ & 0.3048 & meter $(\mathrm{m})$ \\
\hline \multirow[t]{2}{*}{ mile (mi) } & 1.609 & kilometer (km) \\
\hline & Area & \\
\hline square mile $\left(\mathrm{mi}^{2}\right)$ & 2.590 & square kilometer $\left(\mathrm{km}^{2}\right)$ \\
\hline \multicolumn{3}{|c|}{ Volume } \\
\hline gallon (gal) & 3.785 & liter (L) \\
\hline gallon (gal) & 0.003785 & cubic meter $\left(\mathrm{m}^{3}\right)$ \\
\hline million gallons (Mgal) & 3,785 & cubic meter $\left(\mathrm{m}^{3}\right)$ \\
\hline cubic foot $\left(\mathrm{ft}^{3}\right)$ & 0.02832 & cubic meter $\left(\mathrm{m}^{3}\right)$ \\
\hline \multicolumn{3}{|c|}{ Flow rate } \\
\hline foot per day (ft/d) & 0.3048 & meter per day $(\mathrm{m} / \mathrm{d})$ \\
\hline cubic foot per second $\left(\mathrm{ft}^{3} / \mathrm{s}\right)$ & 0.02832 & cubic meter per second $\left(\mathrm{m}^{3} / \mathrm{s}\right)$ \\
\hline cubic foot per day $\left(\mathrm{ft}^{3} / \mathrm{d}\right)$ & 0.02832 & cubic meter per day $\left(\mathrm{m}^{3} / \mathrm{d}\right)$ \\
\hline gallon per minute (gal/min) & 0.06309 & liter per second $(\mathrm{L} / \mathrm{s})$ \\
\hline gallon per day (gal/d) & 0.003785 & cubic meter per day $\left(\mathrm{m}^{3} / \mathrm{d}\right)$ \\
\hline million gallons per day (Mgal/d) & 0.04381 & cubic meter per second $\left(\mathrm{m}^{3} / \mathrm{s}\right)$ \\
\hline inch per year (in/yr) & 25.4 & millimeter per year (mm/yr) \\
\hline \multicolumn{3}{|c|}{ Hydraulic conductivity } \\
\hline foot per day (ft/d) & 0.3048 & meter per day (m/d) \\
\hline \multicolumn{3}{|c|}{ Transmissivity* } \\
\hline foot squared per day $\left(\mathrm{ft}^{2} / \mathrm{d}\right)$ & 0.09290 & meter squared per day $\left(\mathrm{m}^{2} / \mathrm{d}\right)$ \\
\hline
\end{tabular}

Vertical coordinate information is referenced to the National Geodetic Vertical Datum of 1929 (NGVD 29).

Horizontal coordinate information is referenced to the North American Datum of 1983 (NAD 83).

Altitude, as used in this report, refers to distance above the vertical datum.

*Transmissivity: The standard unit for transmissivity is cubic foot per day per square foot times foot of aquifer thickness $\left[\left(\mathrm{ft}^{3} / \mathrm{d}\right) / \mathrm{ft}^{2}\right] \mathrm{ft}$. In this report, the mathematically reduced form, foot squared per day $\left(\mathrm{ft}^{2} / \mathrm{d}\right)$, is used for convenience. 


\section{Acronyms}

CBD

CWS

MPW

RO

RMSE

$\mathrm{SC}$

SCDHEC

USGS
Charleston, Berkeley, and Dorchester Counties Charleston Water System

Mount Pleasant Waterworks

reverse osmosis

root-mean-square error

South Carolina

South Carolina Department of Health and Environmental Control

U.S. Geological Survey 


\title{
Simulation of Reclaimed-Water Injection and Pumping Scenarios and Particle-Tracking Analysis near Mount Pleasant, South Carolina
}

\author{
By Matthew D. Petkewich and Bruce G. Campbell
}

\section{Abstract}

The effect of injecting reclaimed water into the Middendorf aquifer beneath Mount Pleasant, South Carolina, was simulated using a groundwater-flow model of the Coastal Plain Physiographic Province of South Carolina and parts of Georgia and North Carolina. Reclaimed water, also known as recycled water, is wastewater or stormwater that has been treated to an appropriate level so that the water can be reused. The scenarios were simulated to evaluate potential changes in groundwater flow and groundwater-level conditions caused by injecting reclaimed water into the Middendorf aquifer. Simulations included a Base Case and two injection scenarios. Maximum pumping rates were simulated as $6.65,8.50$, and 10.5 million gallons per day for the Base Case, Scenario 1, and Scenario 2, respectively. The Base Case simulation represents a non-injection estimate of the year 2050 groundwater levels for comparison purposes for the two injection scenarios. For Scenarios 1 and 2, the simulated injection of reclaimed water at 3 million gallons per day begins in 2012 and continues through 2050. The flow paths and time of travel for the injected reclaimed water were simulated using particletracking analysis.

The simulations indicated a general decline of groundwater altitudes in the Middendorf aquifer in the Mount Pleasant, South Carolina, area between 2004 and 2050 for the Base Case and two injection scenarios. For the Base Case, groundwater altitudes generally declined about 90 feet from the 2004 groundwater levels. For Scenarios 1 and 2, although groundwater altitudes initially increased in the Mount Pleasant area because of the simulated injection, these higher groundwater levels declined as Mount Pleasant Waterworks pumping increased over time. When compared to the Base Case simulation, 2050 groundwater altitudes for Scenario 1 are between 15 feet lower to 23 feet higher for production wells, between 41 and 77 feet higher for the injection wells, and between 9 and 23 feet higher for observation wells in the Mount Pleasant area. When compared to the Base Case simulation, 2050 groundwater altitudes for Scenario 2 are between 2 and 106 feet lower for production wells and observation wells and between 11 and 27 feet higher for the injection wells in the Mount Pleasant area.
Water budgets for the model area immediately surrounding the Mount Pleasant area were calculated for 2011 and for 2050. The largest flow component for the 2050 water budget in the Mount Pleasant area is discharge through wells at rates between 7.1 and 10.9 million gallons of water per day. This groundwater is replaced predominantly by between 6.0 and 7.8 million gallons per day of lateral groundwater flow within the Middendorf aquifer for the Base Case and two scenarios and through reclaimed-water injection of 3 million gallons per day for Scenarios 1 and 2. In addition, between 175,000 and 319,000 gallons of groundwater are removed from this area per day because of the regional hydraulic gradient. Additional sources of water to this area are groundwater storage releases at rates between 86,800 and 116,000 gallons per day and vertical flow from over- and underlying confining units at rates between 69,100 and 150,000 gallons per day.

Reclaimed water injected into the Middendorf aquifer at three hypothetical injection wells moved to the Mount Pleasant Waterworks production wells in 18 to 256 years as indicated by particle-tracking simulations. Time of travel varied from 18 to 179 years for simulated conditions of 20 percent uniform aquifer porosity and between 25 to 256 years for 30 percent uniform aquifer porosity.

\section{Introduction}

Groundwater use in Mount Pleasant, South Carolina (SC) (fig. 1), combined with irrigation pumpage at Kiawah Island, past use by the town of Summerville, and private industrial use in the Charleston area have created a large, regional cone of depression in the potentiometric surface of the Middendorf aquifer (fig. 2). This cone of depression, which represents groundwater-level declines from predevelopment levels of 106 feet (ft) above land surface (Aucott and Speiran, 1984) to levels as low as $144 \mathrm{ft}$ below land surface (U.S. Geological Survey, 2009a), has led to water-management concerns for Mount Pleasant Waterworks (MPW), the town's public works agency. As a result of these water-level declines, pumping levels in MPW production wells have been as low as several hundred feet below land surface. Previous groundwater 


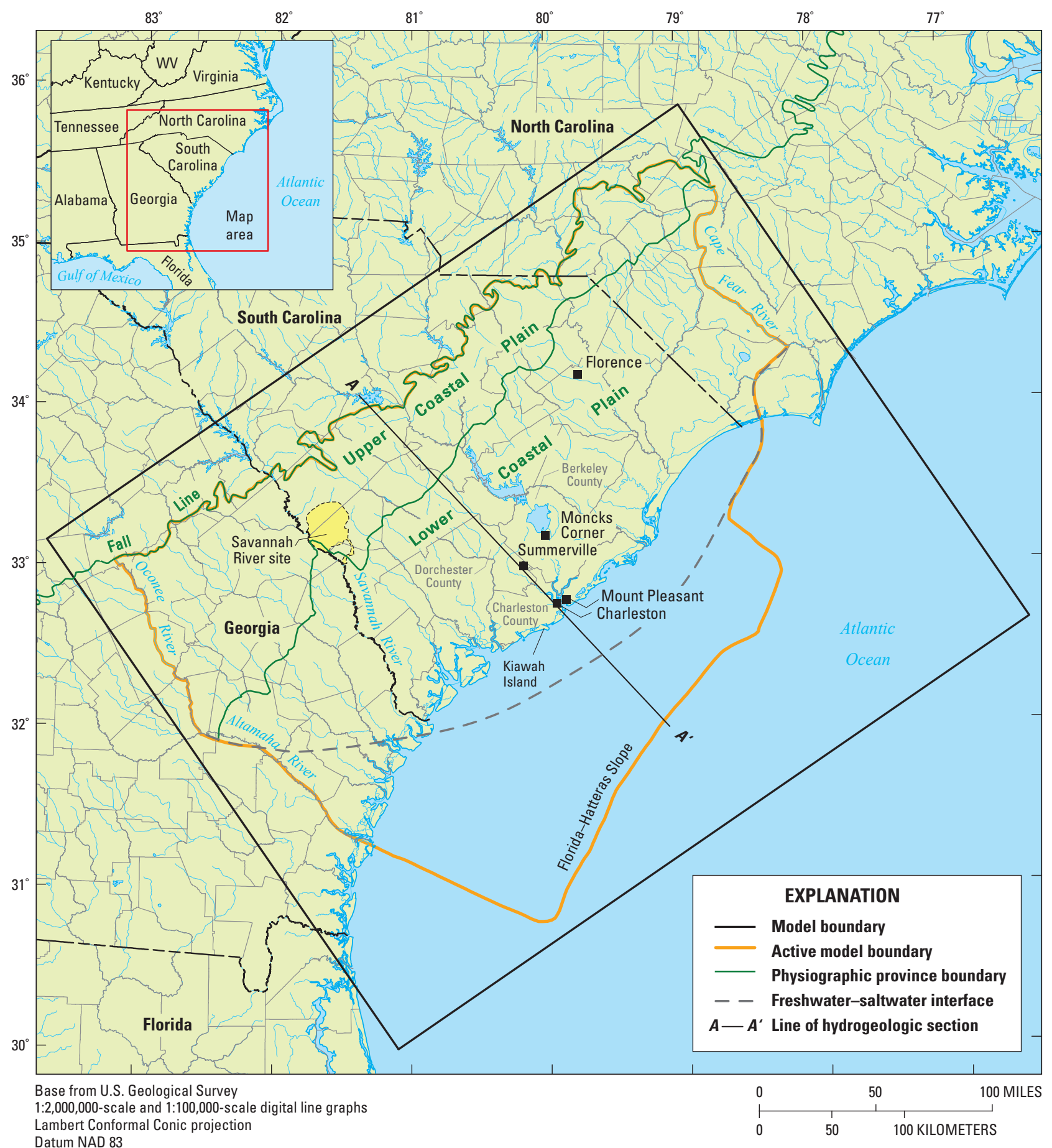

Figure 1. Location of study area and model boundary, Mount Pleasant, South Carolina (modified from Lee and others, 1986; Aucott, 1996). 

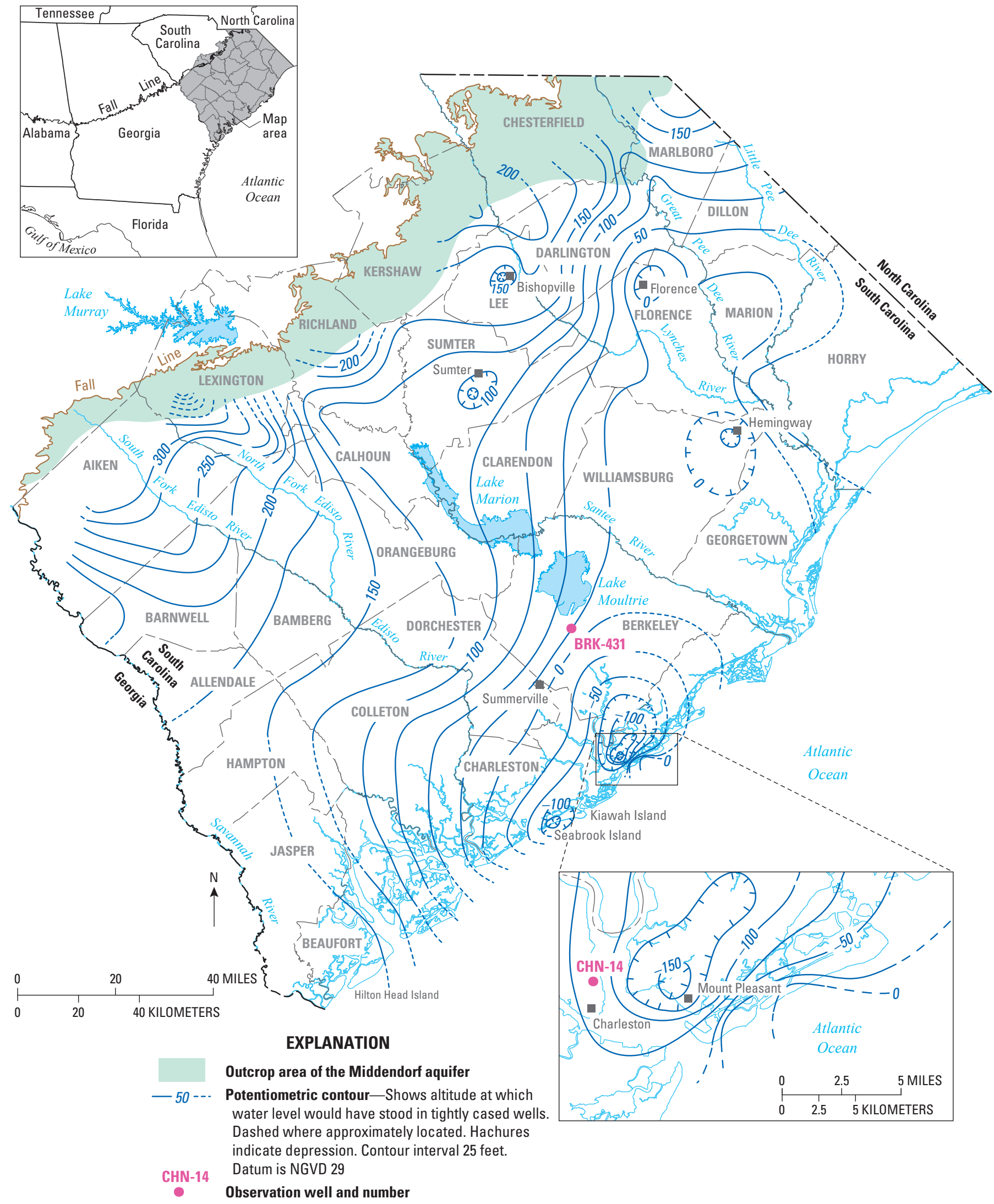

Figure 2. The potentiometric surface of the Middendorf aquifer in South Carolina, November 2004 (modified from Hockensmith, 2008). 
modeling results (Petkewich and Campbell, 2007) indicate that continued pumping in the Charleston, Berkeley, and Dorchester (CBD) County area at 2000-2004 average annual rates would result in additional declines in groundwater levels in the area. Simulations also indicate that reductions in MPW pumping rates by more than 25 percent of the average annual rates would be required to eliminate excessive groundwaterlevel declines in wells near Mount Pleasant.

Mount Pleasant Waterworks has produced potable water from the Middendorf aquifer since 1969. Groundwater-level declines in the Mount Pleasant area due to local pumping can be observed in hydrographs for observation wells CHN-14 and BRK-431 (fig. 3). Water levels in the two wells generally declined from 1989 (year the wells were instrumented with water-level recording equipment) to 2004 (fig. 3A). During 2004, MPW operated six Middendorf wells and four reverse osmosis (RO) plants and withdrew a total of 7.5 million gallons per day (Mgal/d) from the aquifer (fig. 3B). In addition, MPW purchased $1.5 \mathrm{Mgal} / \mathrm{d}$ of treated surface water from Charleston Water System (CWS) to meet the water demand for the Town of Mount Pleasant. Currently (2008), the water demand for the Town of Mount Pleasant is met by purchasing $5.5 \mathrm{Mgal} / \mathrm{d}$ of treated surface water from CWS and supplemented by the Middendorf wells and RO plants as needed. During 2008, 3.5 Mgal/d was pumped from MPW wells to help meet the $8.5 \mathrm{Mgal} / \mathrm{d}$ average daily water demand in Mount Pleasant. Because some of the aquifer water is unusable after the RO treatment process, part of the $3.5 \mathrm{Mgal} / \mathrm{d}$ was
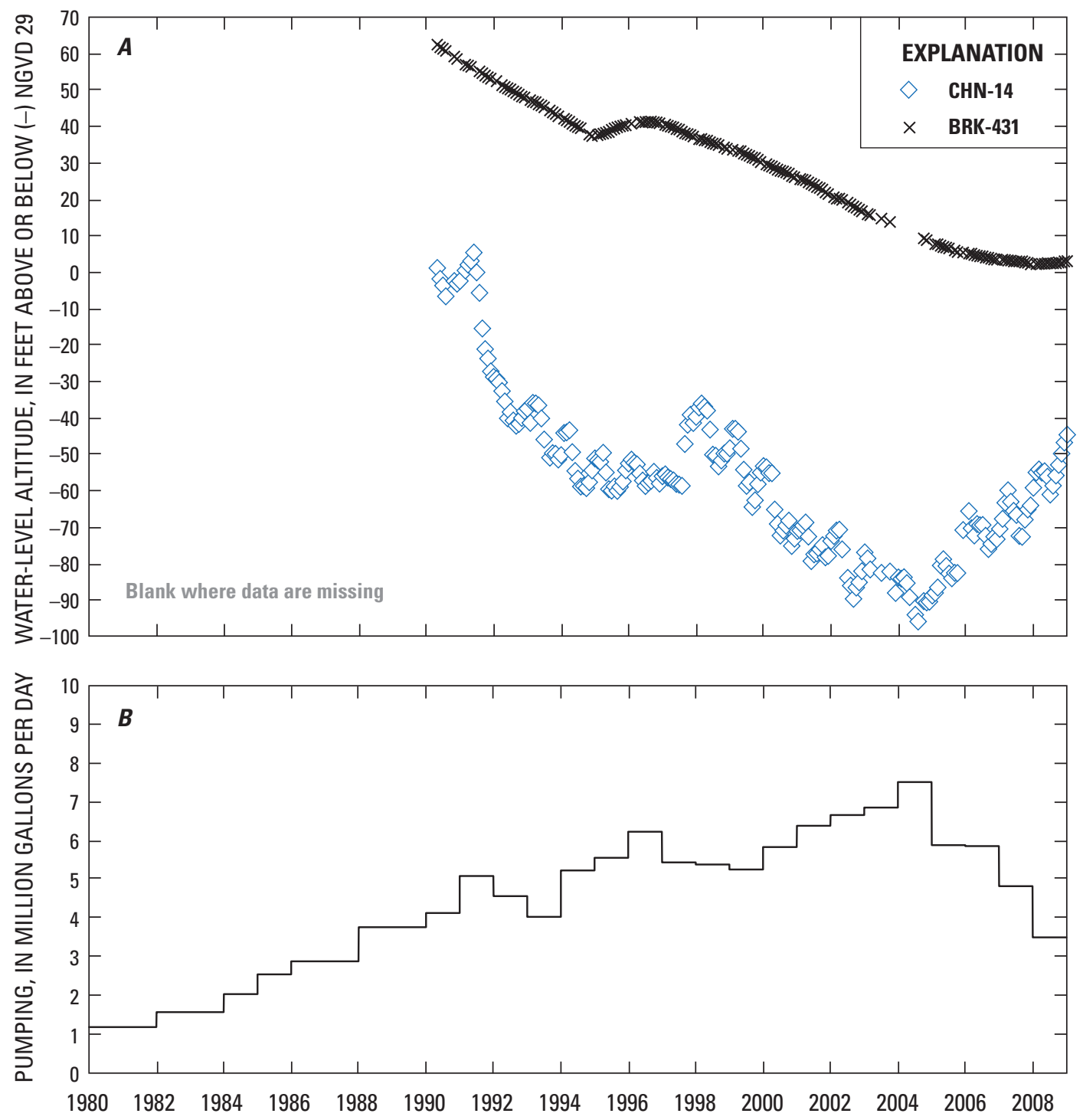

Figure 3. Hydrographs of (A) BRK-431 observation well near Moncks Corner, South Carolina, and CHN-14 observation well in Charleston, South Carolina, and (B) pumping from wells in Mount Pleasant, South Carolina. 
not distributed to water users. The reduction in MPW pumping from 7.5 Mgal/d during 2004 to $3.5 \mathrm{Mgal} / \mathrm{d}$ during 2008 has resulted in a recovery (increase) of the groundwater levels in the Middendorf aquifer in the Mount Pleasant area (fig. 3). Water-level altitude in $\mathrm{CHN}-14$ has increased from a minimum of $-97 \mathrm{ft}$ during 2004 to about $-45 \mathrm{ft}$ during December 2008 (fig. 3A; U.S. Geological Survey, 2009b). Observation well BRK-431 is located approximately 25 miles (mi) from the MPW well field and, therefore, has not experienced significant recovery in water-level altitudes due to reduced MPW pumping. Drawdown in this well, however, has been eliminated, and water-level altitudes are currently recovering (fig. $3 \mathrm{~A}$ ).

Reclaimed water, also known as recycled water, is wastewater or stormwater that has been treated to an appropriate level so that the water can be reused (U.S. Environmental Protection Agency, 2004). Reclaimed water is being used throughout the world for many purposes, including agricultural and golf-course irrigation, cooling of industrial equipment, and recharging aquifers (O’Reilly, 1998; Aiken and Kuniansky, 2002; U.S. Geological Survey, 2009c). In addition to reducing pumpage from the Middendorf aquifer to alleviate the stress on this water source, MPW is investigating the possibility of injecting highly treated reclaimed water into the Middendorf aquifer where it would be available for future use.

To evaluate the effect of injecting reclaimed water into the Middendorf aquifer, the U.S. Geological Survey (USGS), in cooperation with the MPW, updated an existing groundwater-flow model (Petkewich and Campbell, 2007) to incorporate water-use data from 2005 through 2008 and simulated three water-management scenarios to the year 2050. The results of this investigation will provide MPW and groundwater users of other aquifers of Cretaceous age in the Charleston area with an indication of the overall hydraulic effects of injecting reclaimed water over time.

\section{Purpose and Scope}

This report describes modeling efforts to determine the effect of recent (2005-2008) water use and potential future reclaimed-water injection on groundwater levels in the Middendorf aquifer near Mount Pleasant, SC. Changes in groundwater levels near Mount Pleasant were evaluated for the period between 2004 and 2008 and projected to 2050 by updating an existing groundwater-flow model (Petkewich and Campbell, 2007). The update included incorporation of 2005-2007 water-use data for wells located within the South Carolina Coastal Plain and estimated recharge data acquired since the previous study. After updating the model, three water-management scenarios were simulated to evaluate the potential changes in groundwater-level conditions caused by injecting reclaimed water into the Middendorf aquifer. Particle-tracking analysis was used to simulate the groundwater-flow paths and times of travel for reclaimed water injected through hypothetical wells.

\section{Description of Study Area}

The study area is described in detail in Petkewich and Campbell (2007); only a brief description is included in the current report. The study area (fig. 1) extends from the Fall Line in the northwest to the Florida-Hatteras Slope off the Georgia coast (Payne and others, 2005) and the freshwatersaltwater interface off the South Carolina and North Carolina coast (Lee and others, 1986). The lateral boundaries extend from the Oconee and Altamaha Rivers in Georgia to the Cape Fear River in North Carolina. As in the previous investigation (Petkewich and Campbell, 2007), the focus of the current investigation is the six major aquifers within the Coastal Plain aquifer system in South Carolina and parts of Georgia and North Carolina (fig. 4; Aucott and Speiran, 1985; Aucott, 1996) and, in particular, the Middendorf aquifer near Mount Pleasant, SC. Land-surface altitudes range from $0 \mathrm{ft}$ at the coast to more than $600 \mathrm{ft}$ in the upper Coastal Plain Physiographic Province (Aucott, 1996). The offshore part of the study area ranges from $0 \mathrm{ft}$ to more than $300 \mathrm{ft}$ below the National Geodetic Vertical Datum of 1929 (NGVD 29).

Aucott and Speiran (1985) described six major aquifers within the Coastal Plain aquifer system in South Carolina. From youngest to oldest these aquifers are the surficial, Floridan aquifer system, Tertiary sand, Black Creek, Middendorf, and Cape Fear aquifers (fig. 4). The aquifers were divided into units on the basis of relative permeability and not geologic formation; therefore, aquifers may cross formation boundaries in some instances (Aucott, 1996). While previous and ongoing investigations in the study area use different nomenclature to describe these aquifers, this report uses the nomenclature described in Aucott and Speiran (1985), Aucott (1988, 1996), Campbell and van Heeswijk (1996), and Petkewich and Campbell (2007).

Hydraulic properties reported for the aquifers of the Coastal Plain are listed in table 1 (Aucott and Newcome, 1986; Newcome, 1993, 2000; Temples and Wadell, 1996; Payne and others, 2005; M. Peck, U.S. Geological Survey, written commun., December 2005; D. Payne, U.S. Geological Survey, written commun., January 2006). The Floridan aquifer system and Tertiary sand aquifer were considered one aquifer in this investigation similar to previous modeling investigations (Aucott, 1988; Campbell and van Heeswijk, 1996; Petkewich and Campbell, 2007).

Mean annual precipitation in Georgia, South Carolina, and North Carolina varies between about 48 and 50 inches and occurs predominantly as rainfall with occasional snowfall during the winter. The areal distribution of annual precipitation ranges from below 40 to more than 90 inches for these States, with the lowest rainfall occurring in the Coastal Plain Physiographic Province and the highest rainfall occurring in the Blue Ridge Mountains. Annual rainfall for the Coastal Plain Physiographic Province ranges from about 46 to 58 inches for Georgia, 42 to 56 inches for South Carolina, and 44 to 62 inches for North Carolina (Oregon Climate Service, 2007). 


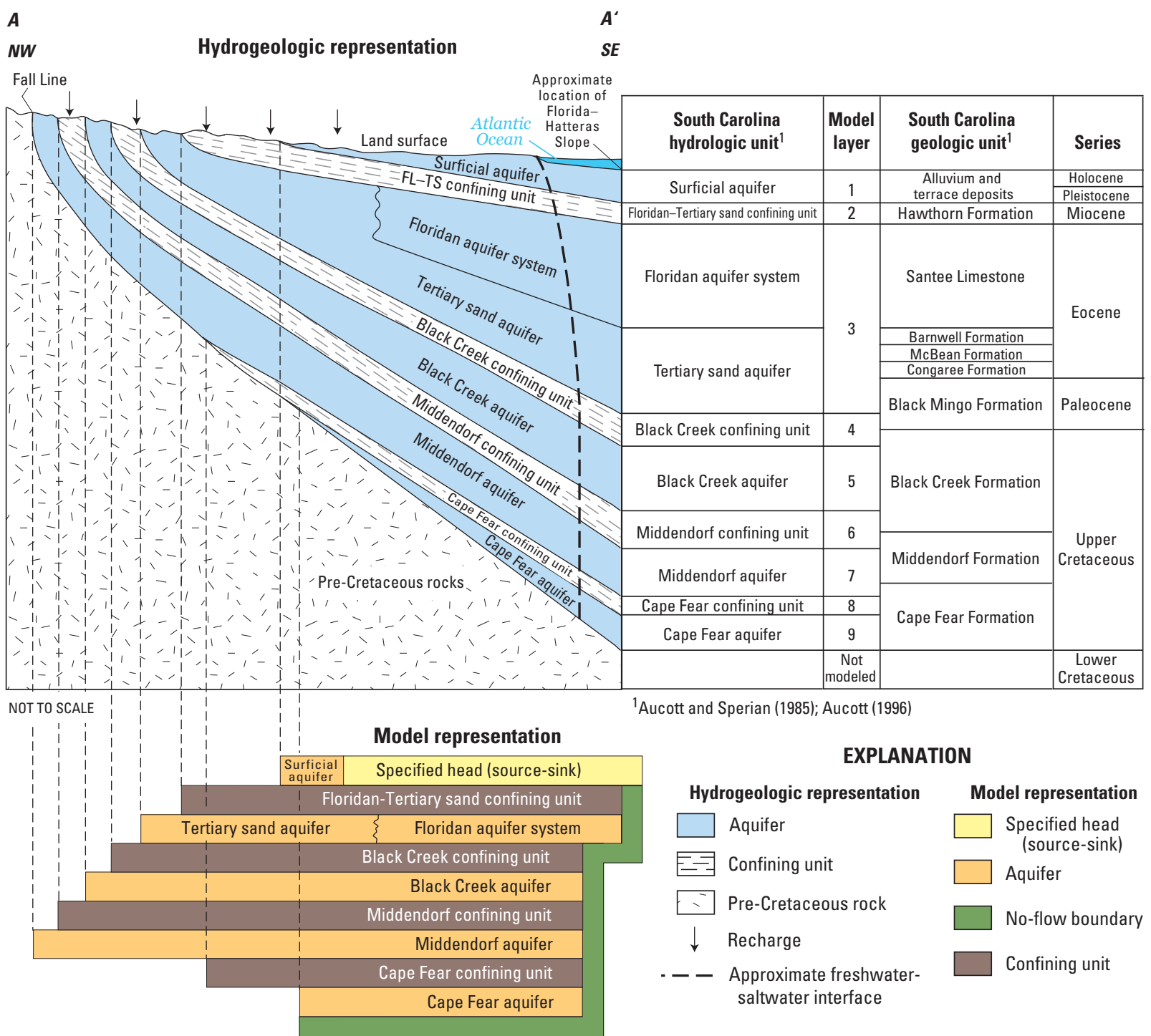

Figure 4. Hydrogeologic framework, model layers, and boundary conditions across the South Carolina Coastal Plain (modified from Aucott and Speiran, 1985; Aucott, 1996; Petkewich and Campbell, 2007).

Table 1. Ranges of reported aquifer transmissivity, storage coefficient, calculated horizontal hydraulic conductivity, and simulated horizontal hydraulic conductivity for the aquifers in the study area.

[ft²/d, feet squared per day; ft/d, feet per day; —, data not available $]$

\begin{tabular}{|c|c|c|c|c|c|c|c|c|c|c|c|c|c|}
\hline \multirow[b]{2}{*}{ Aquifer } & \multirow[b]{2}{*}{ Layer } & \multicolumn{3}{|c|}{$\begin{array}{l}\text { Reported transmissivity, } \\
\text { in } \mathrm{ft}^{2} / \mathrm{d}\end{array}$} & \multicolumn{3}{|c|}{$\begin{array}{l}\text { Reported storage } \\
\text { coefficient }\end{array}$} & \multicolumn{6}{|c|}{$\begin{array}{l}\text { Horizontal hydraulic conductivity, } \\
\text { in } \mathrm{ft} / \mathrm{d}\end{array}$} \\
\hline & & $\begin{array}{l}\text { Mini- } \\
\text { mum }\end{array}$ & $\begin{array}{l}\text { Med- } \\
\text { ian }\end{array}$ & $\begin{array}{l}\text { Maxi- } \\
\text { mum }\end{array}$ & $\begin{array}{l}\text { Mini- } \\
\text { mum }\end{array}$ & $\begin{array}{l}\text { Med- } \\
\text { ian }\end{array}$ & $\begin{array}{l}\text { Maxi- } \\
\text { mum }\end{array}$ & \multicolumn{3}{|c|}{ Calculated } & \multicolumn{3}{|c|}{ Simulated } \\
\hline Surficial $^{1}$ & 1 & - & - & - & - & - & - & 12 & 67 & 240 & 13 & 110 & 390 \\
\hline Middendorf & 7 & 130 & 3,100 & 31,000 & 0.0001 & 0.0002 & 0.002 & 2.7 & 46 & 360 & 1.0 & 16 & 500 \\
\hline Cape Fear & 9 & 450 & 900 & 1,300 & - & - & - & 8.9 & 11 & 11 & 1.1 & 3.3 & 56 \\
\hline
\end{tabular}

${ }^{1}$ The calculated horizontal hydraulic conductivity is equal to the reported horizontal hydraulic conductivity for the surficial aquifer. 


\section{Acknowledgments}

The authors thank the personnel of Mount Pleasant Waterworks, especially Clay Duffie, David Niesse, and Jim Ouellet, for assistance in collecting hydrologic and water-use data in the Mount Pleasant area during this investigation. The authors thank Alex Butler from the South Carolina Department of Health and Environmental Control and Becky Dennis from Kiawah Island Utility, Inc., for water-use data for production wells in the study area.

\section{Simulation of Groundwater Flow}

The groundwater-flow system of the Coastal Plain Physiographic Province of South Carolina and parts of Georgia and North Carolina was simulated using the USGS finite-difference code MODFLOW-2000 (Harbaugh and others, 2000) and the conceptual model described in Petkewich and Campbell (2007). The model consisted of 29 stress periods that simulated a steady-state predevelopment (1900) period followed by a transient period ending in 2004. Updates to the calibrated model consisted of incorporating reported or assumed 2005-2050 water-use data and estimated recharge data. All other boundary conditions and model inputs remained equal to the calibrated model. Twenty-five stress periods were added to simulate the time period between 2005 and 2050. Stress period lengths varied from 1-year stress periods through 2022, 2-year stress periods through 2026, a single 3-year stress period ending in 2029, and four, 5-year stress periods between 2030 and 2050.

The calibrated model was updated by adding reported water-use data for the years 2005-2007 (A. Butler, South Carolina Department of Health and Environmental Control, written commun., December 2008). Because the 2008 wateruse data were not available for this investigation, pumping rates for 2008-2050 were set equal to 2007 values for all wells in the study area except for six active wells located in Mount Pleasant (fig. 5) and one well located on Kiawah Island, all screened in the Middendorf aquifer. Pumping rates for 2008 were obtained for these seven wells and simulated as reported (B. Dennis, Kiawah Island Utility, Inc., written commun., December 2008; J. Ouellet, Mount Pleasant Waterworks, written commun., January 2009). The 2008 pumping rate was used as the average pumping rate for years 2008-2050 for the Kiawah Island well. For 2009-2050, the pumping rates for the MPW wells varied for the different scenarios as described below. New wells were added to the model for the CBD County area to account for recent water-use data and only when the location and well depth information was included in the water-use data (A. Butler, South Carolina Department of Health and Environmental Control, written commun., December 2008). New wells located outside the CBD County area were not added to the model. This three-county area is the primary focus of this investigation, and pumping from wells located outside this area should have a relatively minimal effect on Middendorf aquifer groundwater levels within this area. Five new Floridan aquifer system wells and one new Middendorf aquifer well located in the CBD County area had location and well-depth information included in the water-use data and, therefore, were added to the model for this investigation.

While updating the water-use data for the model, it was determined that some of the water-use data used in the calibrated model was different than that of the historical record. Between 1984 and 1992, the simulated pumping was between 0.55 and $3.0 \mathrm{Mgal} / \mathrm{d}$ lower than that contained in the historical record from MPW (M. Bennett, Mount Pleasant Waterworks, written commun., 1993). While the causes of the discrepancies are unclear, some of the differences are due to at least one transcription error in the South Carolina Department of Health and Environmental Control (SCDHEC) water-use database and 1 year of missing data for the MPW wells. The simulated pumping data presented in Petkewich and Campbell (2007) were adjusted to match that of the historical record from MPW. Because MPW record (M. Bennett, Mount Pleasant Waterworks, written commun., 1993) listed composited pumpage, rather than pumping on a per well basis, the 1984-1992 data were re-apportioned to individual MPW wells based on the percentage rates contained in the SCDHEC water-use report (J. Childress, South Carolina Department of Health and Environmental Control, written commun., March 2005).

Simulated recharge rates varied over time and were calibrated on the basis of average precipitation data from six weather stations located in the upper Coastal Plain section of the study area (Petkewich and Campbell, 2007). For each stress period, increases or decreases in the calibrated recharge rate covaried with relative changes in the average annual precipitation for the six stations. Recharge estimates were updated for 2005, 2006, and 2007 using precipitation data from the National Weather Service (Southeast Regional Climatic Data Center, 2009a-c) and were set to 3.9, 3.9, and 3.8 inches per year (in/yr), respectively. For 2008-2050, the recharge rates were assumed and set equal to an annual average recharge rate of $3.8 \mathrm{in} / \mathrm{yr}$. Only three (380074-Aiken, SC; 381588-Cheraw, SC; 381944-University of South Carolina, Columbia, SC) of the six precipitation stations described in Petkewich and Campbell (2007) were still in operation in 2007; therefore, the simulated recharge rates for 2005-2007 were determined from the average precipitation of these three stations.

\section{Groundwater Conditions}

Since 2004, water-level altitudes in the Middendorf aquifer have recovered in the Mount Pleasant area as a result of reduced withdrawals by MPW (fig. 3). During 2004-2008, MPW increased surface-water withdrawals from CWS from 1.5 to $5.5 \mathrm{Mgal} / \mathrm{d}$ (J. Ouellet, Mount Pleasant Waterworks, written commun., October 2008). Average annual 


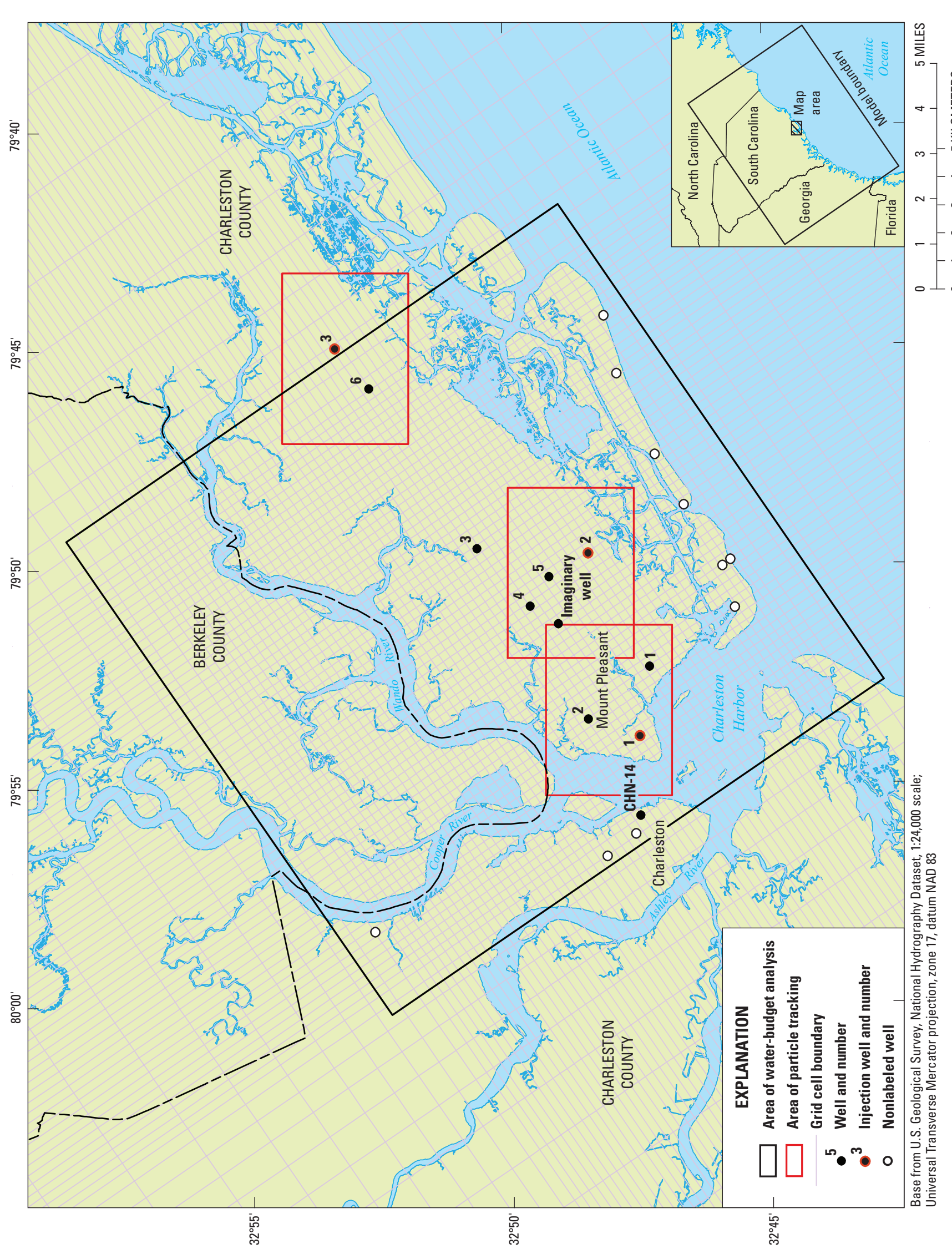

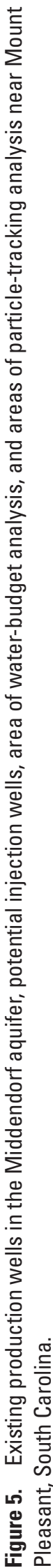


MPW pumping decreased from $7.5 \mathrm{Mgal} / \mathrm{d}$ during 2004 to 3.5 Mgal/d during 2008 (fig. 3B). In addition, the reported water use from the Middendorf aquifer in the CBD area decreased from 2004 to 2005 and remained relatively stable during 2006 and 2007 (fig. 6). Although 2008 water-use data are not currently available for all water users, total water use from the Middendorf aquifer was expected to be lower for the CBD area during 2008 compared to 2007 due to the decreased MPW pumpage. As a result of the reduced MPW pumping, the groundwater altitude recovered $52 \mathrm{ft}$ from 2004 to 2008 in observation well CHN-14 (fig. 3A; U.S. Geological Survey, 2009b). The recovery of groundwater altitudes in the area also is evident in the hydrograph for observation well BRK-431 (fig. 3A; U.S. Geological Survey, 2009d). The long-term downward trend for BRK-431 has been eliminated because of the reduced pumping.

The simulated 2008 groundwater altitude for CHN-14 using the Petkewich and Campbell (2007) model and updated water use and recharge was $27.5 \mathrm{ft}$ lower than the observed value (fig. $7 A$ ). The simulated recovery of groundwater levels in the Mount Pleasant area is less than the measured values in observation well CHN-14. This discrepancy could be due to multiple factors, including model cell dimensions, length of modeled stress periods, or uncertainties in pumping rates and volumes. The vast model area, number of model layers, and associated large number of model cells precluded the ability to refine the cell dimensions any smaller than $1,000 \mathrm{ft}$ by $1,000 \mathrm{ft}$ in the Mount Pleasant area. The addition of more cells in the area would have inhibited model calibration within the timeframe of the original investigation. In addition, the minimum length of a modeled stress period was selected to be 1 year. While dividing the yearly stress periods into monthly (or smaller) stress periods would have allowed better representation of monthly pumping rates and would have helped to simulate the water-level fluctuations observed at well CHN-14 throughout the year, the additional numerical processing required by that exercise also would have increased the length of the investigation beyond an acceptable limit. Finally, the omission of unreported water-use data (water use less than $3 \mathrm{Mgal}$ per month is not required to be reported to SCDHEC) or the calibration of the model to periods of inaccurate water-use data may have resulted with calibrated hydraulic properties that can fit the general trend of the groundwaterlevel data, but do not precisely match yearly data.

Because the simulated 2008 groundwater altitude for CHN-14 was poor and the predicted groundwater altitude at this well was to be used by MPW to make water-management decisions, the simulated hydraulic properties in the Middendorf aquifer were adjusted to allow a better fit of the 2005-2008 groundwater-level data for this well. The recalibration process consisted of a technique of parameter estimation that uses regularized inversion (Doherty, 2003, 2005) and employs "pilot points" for spatial hydraulic property characterization. A detailed description of how this method was used for the Mount Pleasant model is described in Petkewich and Campbell (2007). For the recalibrated model, instead of allowing all 434 of the previously calibrated parameters to adjust during calibration, only 18 parameters were allowed to adjust. These parameters were the specific storage of the Middendorf aquifer and 17 horizontal hydraulic conductivity pilot points located in the Mount Pleasant model area (fig. 8). These 18 parameters were selected because changes to them provided the best chance of an improved calibration while minimizing the total number of parameters requiring change. To improve the calibration of the model by improving the fit of simulation results to 2005-2008 water-level data at CHN-14 and BRK-431, hydraulic properties in the vicinity of these two wells and the Mount Pleasant production wells needed to be changed. Changing simulated hydraulic properties in other aquifers or confining units at more distant locations from the Mount Pleasant well field would have had a lesser effect on model recalibration than focusing on hydraulic properties in the vicinity. The strategy of limiting the number and areal location of parameters that were allowed to adjust during recalibration facilitated a better fit of the modeled data near Mount Pleasant, SC, while limiting the overall change to the original, calibrated model. The effort required for a completely new calibration was beyond the scope of this investigation.

The recalibration process produced a potentiometric surface of the Middendorf aquifer (fig. 9) that was relatively similar to the previous calibration. The largest water-level differences between the two calibrated versions of the model occurred in the Mount Pleasant, SC, area where the MPW well field is located (fig. 10). Within this area, the Middendorf aquifer groundwater-level altitudes are between 7 and $73 \mathrm{ft}$ higher for the recalibrated potentiometric surface compared to the original water levels (fig. 10). Outside the CBD area, the maximum difference in groundwater-level altitudes is less than $7 \mathrm{ft}$. The root-mean-square error (RMSE) for the Middendorf aquifer changed from 34.4 to 34.5 for the predevelopment time period and from 36.7 to 36.4 for the 2004 time period. Net changes to horizontal hydraulic conductivity pilot points ranged from -32 percent to 54 percent (table 2). Changes in the calibrated hydraulic conductivity values are shown in figure 8 . None of the changes were greater than an order of magnitude and all were deemed within the confidence limits of aquifer-test data. The calibrated specific storage value for the Middendorf aquifer changed from 0.0000025 to 0.0000029 per foot during recalibration, which is within reasonable limits for confined aquifers.

The recalibrated model produced a simulated groundwater level for $\mathrm{CHN}-14$ that was $17 \mathrm{ft}$ lower than the average groundwater level measured in 2008 (fig. 7A). While this result is not ideal, it is better than the previous calibration, which produced a simulated $\mathrm{CHN}-14$ water level that was $27 \mathrm{ft}$ lower than the 2008 average observed value at CHN-14. The recalibrated model provides a better starting point for scenario modeling compared to the previous calibration. Although the simulated results at $\mathrm{CHN}-14$ still under-predict the 2008 groundwater level, the calibrated model can be used to predict relative changes in groundwater levels over time. The simulated results can be considered a conservative low estimate for the three scenarios. 


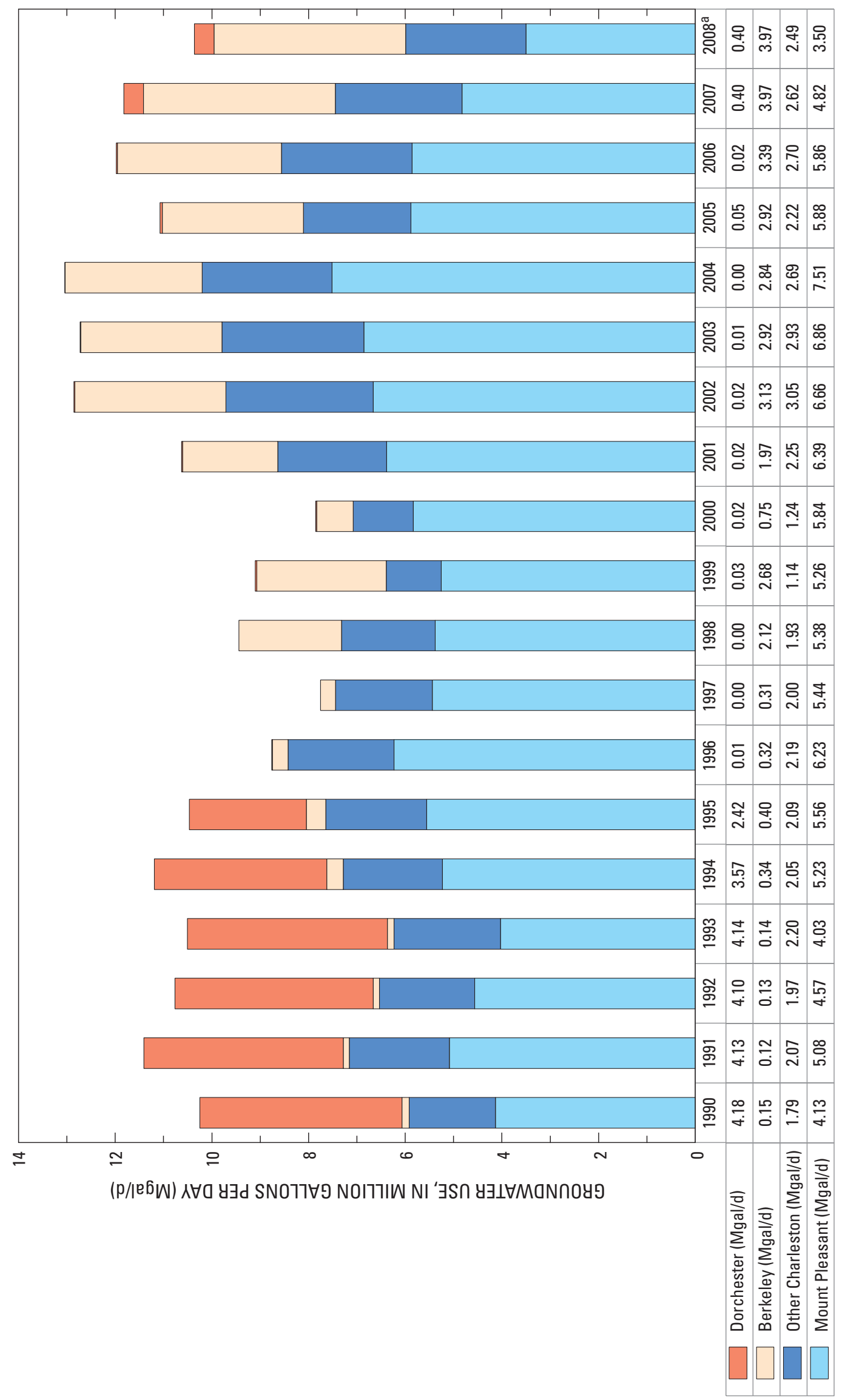

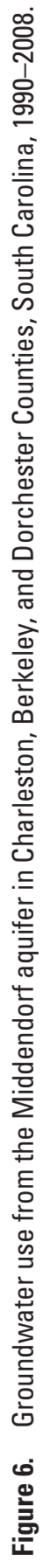




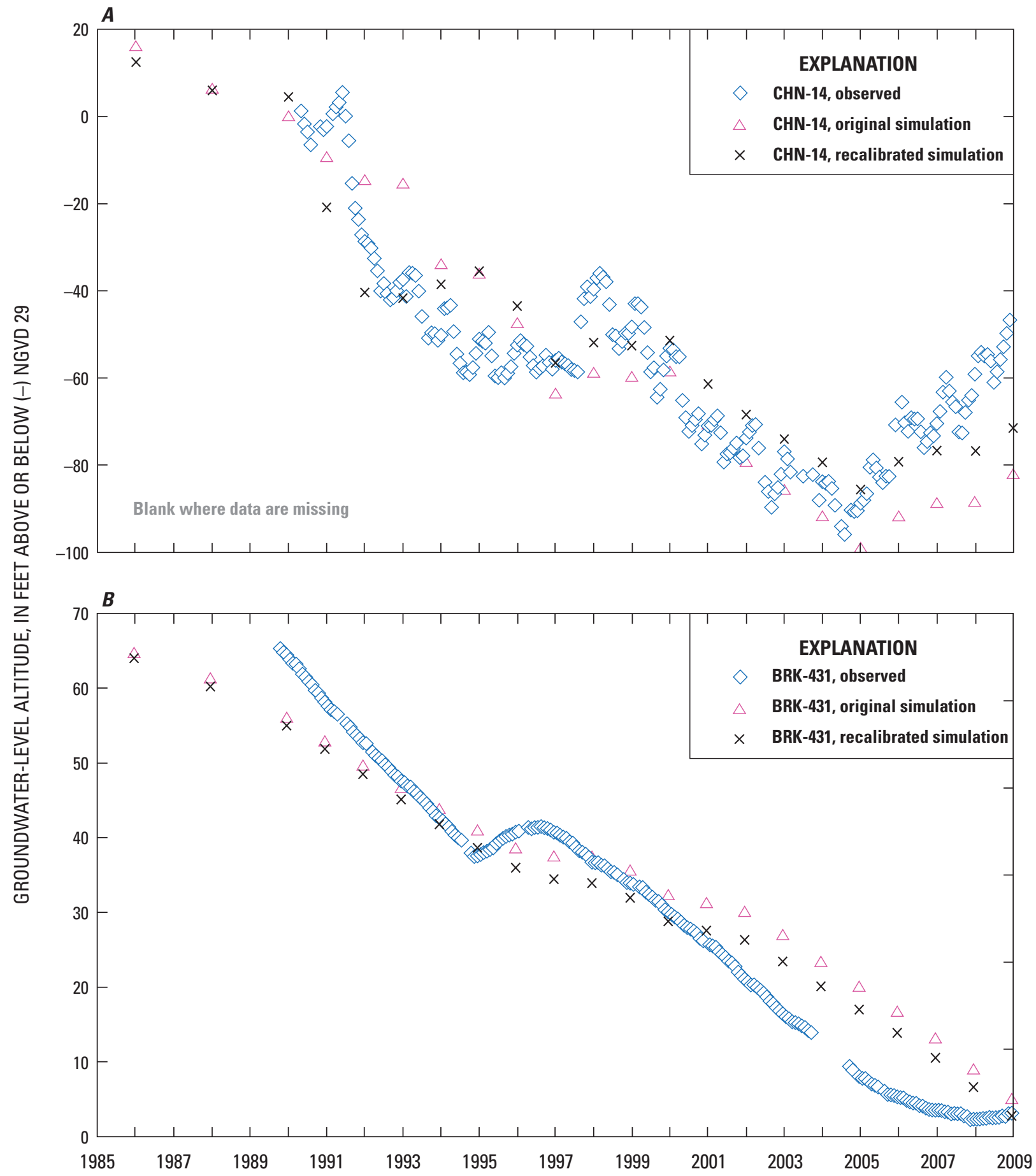

Figure 7. Measured and simulated groundwater altitudes for observation wells (A) CHN-14 in Charleston, South Carolina, and (B) BRK-431 near Moncks Corner, South Carolina. 


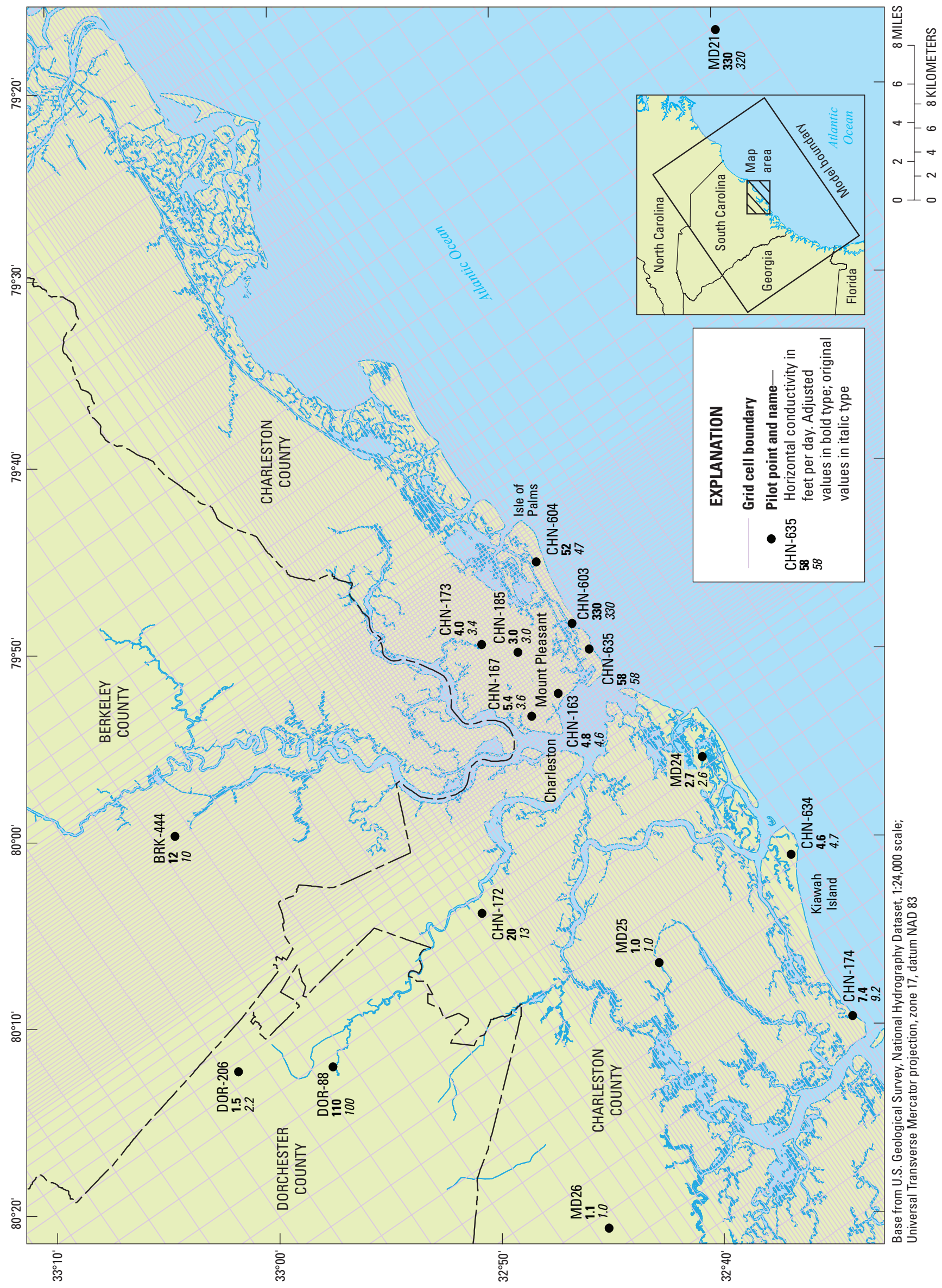




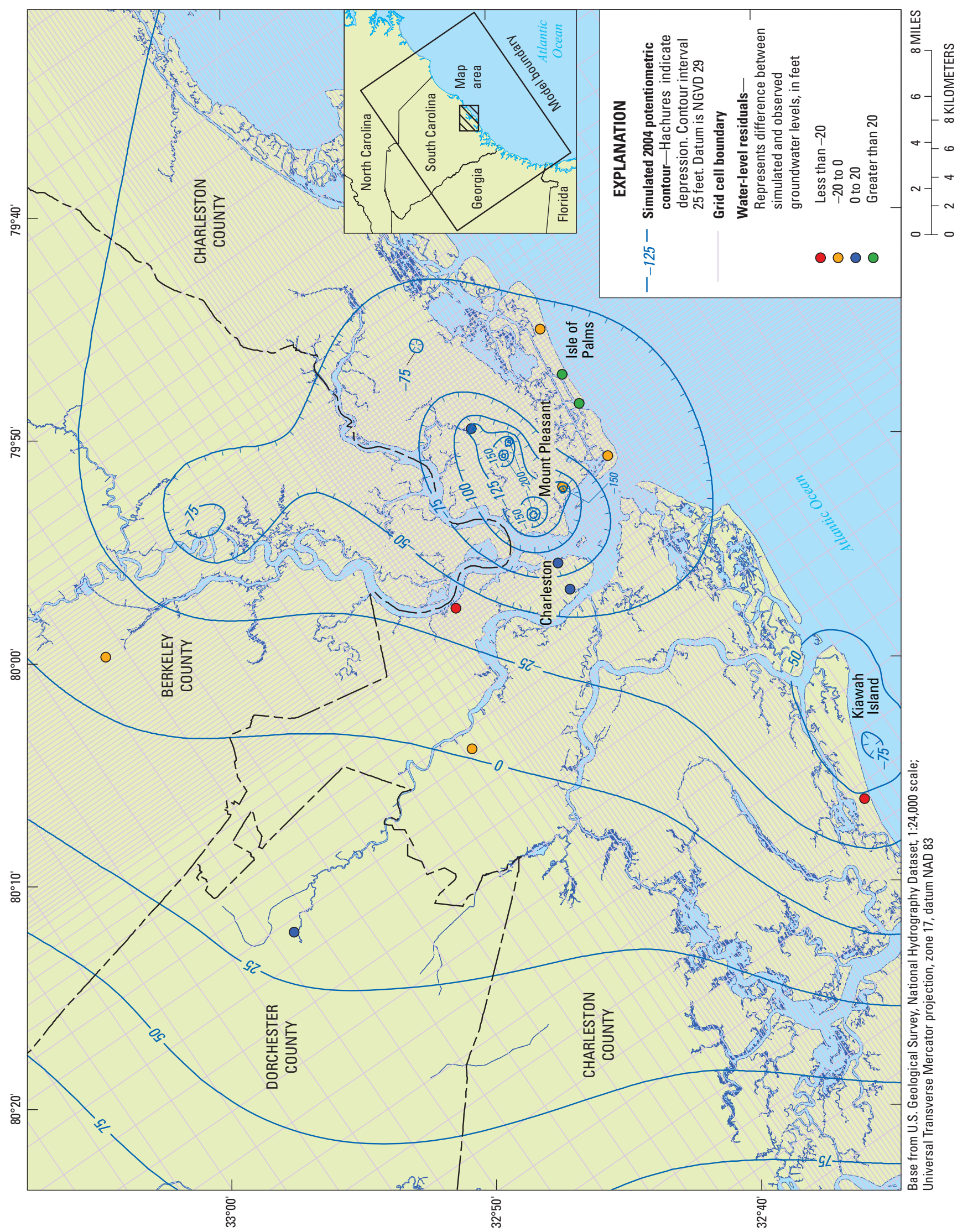

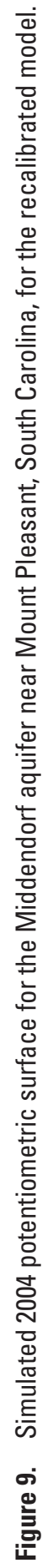




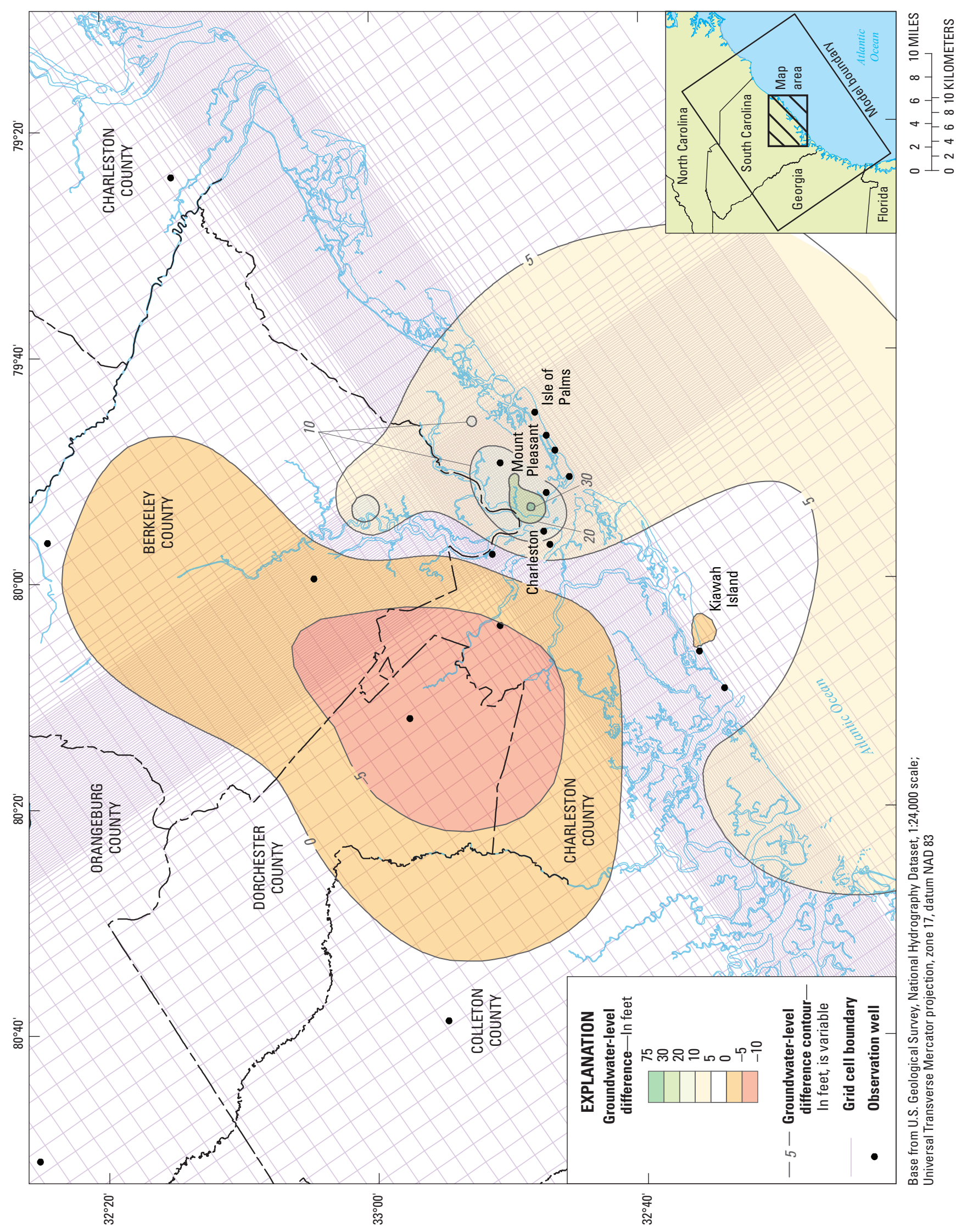

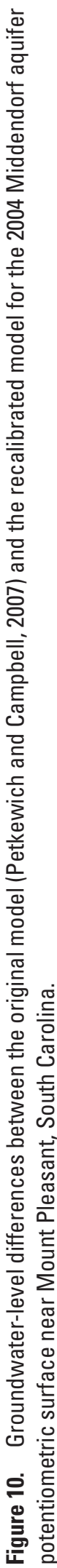


Table 2. Changes made to the Middendorf aquifer specific storage and horizontal hydraulic conductivity pilot-point values during recalibration of the Mount Pleasant, South Carolina, model (Petkewich and Campbell, 2007).

\begin{tabular}{|c|c|c|c|c|}
\hline \multirow{2}{*}{$\begin{array}{c}\text { Pilot-point name } \\
\text { (see fig. } 8 \text { for locations } \\
\text { of hydraulic conductivity } \\
\text { pilot points) }\end{array}$} & \multirow[b]{2}{*}{ Units } & \multicolumn{2}{|c|}{ Parameter value } & \multirow[b]{2}{*}{ Percent difference } \\
\hline & & $\begin{array}{c}\text { Updated } \\
\text { calibration }\end{array}$ & $\begin{array}{c}\text { Original } \\
\text { calibration }\end{array}$ & \\
\hline Specific storage & $1 /$ foot & $2.9 \mathrm{E}-6$ & $2.5 \mathrm{E}-6$ & 16 \\
\hline BRK-444 & feet/day & 12 & 10 & 20 \\
\hline CHN-163 & feet/day & 4.8 & 4.6 & 4.3 \\
\hline CHN-167 & feet/day & 5.4 & 3.6 & 50 \\
\hline CHN-172 & feet/day & 20 & 13 & 54 \\
\hline CHN-173 & feet/day & 4.0 & 3.4 & 18 \\
\hline CHN-174 & feet/day & 7.4 & 9.2 & -20 \\
\hline CHN-185 & feet/day & 3.0 & 3.0 & 0.0 \\
\hline CHN-603 & feet/day & 330 & 330 & 0.0 \\
\hline CHN-604 & feet/day & 52 & 47 & 11 \\
\hline CHN-634 & feet/day & 4.6 & 4.7 & -2.1 \\
\hline CHN-635 & feet/day & 58 & 58 & 0.0 \\
\hline DOR-88 & feet/day & 110 & 100 & 10 \\
\hline DOR-206 & feet/day & 1.5 & 2.2 & -32 \\
\hline $\operatorname{MD} 21 *$ & feet/day & 330 & 320 & 3.1 \\
\hline MD24* & feet/day & 2.7 & 2.6 & 3.8 \\
\hline MD25* & feet/day & 1.0 & 1.0 & 0.0 \\
\hline MD26* & feet/day & 1.1 & 1.0 & 10 \\
\hline
\end{tabular}

*Pilot points labeled as MD21, MD24, MD25, MD26 are not associated with any known wells.

The recalibrated model produced simulated groundwater altitudes for BRK-431 that were slightly lower than the original calibration (fig. $7 B$ ). Simulation results of groundwater levels are higher than the observed groundwater altitude for BRK-431 for most of the time period between 2001 and 2009 (fig. 7B). Since 2007, the observed groundwater altitude at BRK-431 has been level or rising. Simulation results for 2008 indicate a good match with observed values for BRK-431 and provide a good starting point for the scenario modeling.

\section{Reclaimed-Water Injection and Pumping Scenarios}

The recalibrated groundwater-flow model was used to simulate three predictive water-management scenarios for 2009-2050 for the Middendorf aquifer in the Mount Pleasant, SC, area (fig. 5). Scenario results should show the effect of injecting reclaimed water into the Middendorf aquifer and facilitate water-management plans to use the Middendorf aquifer for water resource and storage. Injection wells were simulated at locations near where MPW infrastructure currently exists or could be constructed if needed. The locations were selected at a distance of at least $1 \mathrm{mi}$ from the nearest Middendorf aquifer production well. A 1-mi buffer zone between injection wells and production wells creates a 1-mi zone where mixing and filtering will occur as the injected reclaimed water moves through the aquifer to the production wells. This design prohibits reclaimed water from being pumped from the Middendorf aquifer and distributed to water users after relatively short injection and storage periods. Simulated MPW pumping rates for the three scenarios are listed in tables 3-5. Average annual pumping rates for the individual MPW wells were apportioned on the basis of the best estimates for future water use (J. Ouellet, Mount Pleasant Waterworks, written commun., January 2009). For all three scenarios, the total MPW pumping rate changed uniformly from the 2008 rate of $3.5 \mathrm{Mgal} / \mathrm{d}$ to $5.0 \mathrm{Mgal} / \mathrm{d}$ in the year 2018. Between 2018 and 2023, the MPW rate changed 


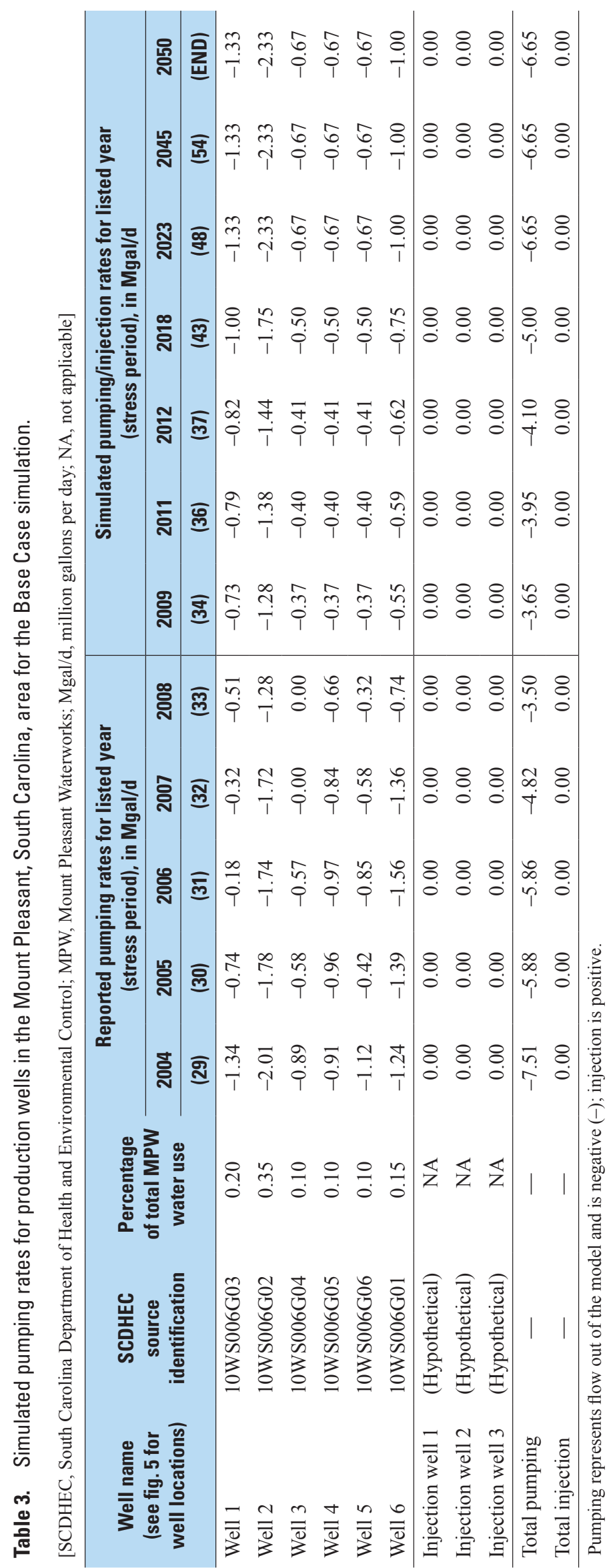




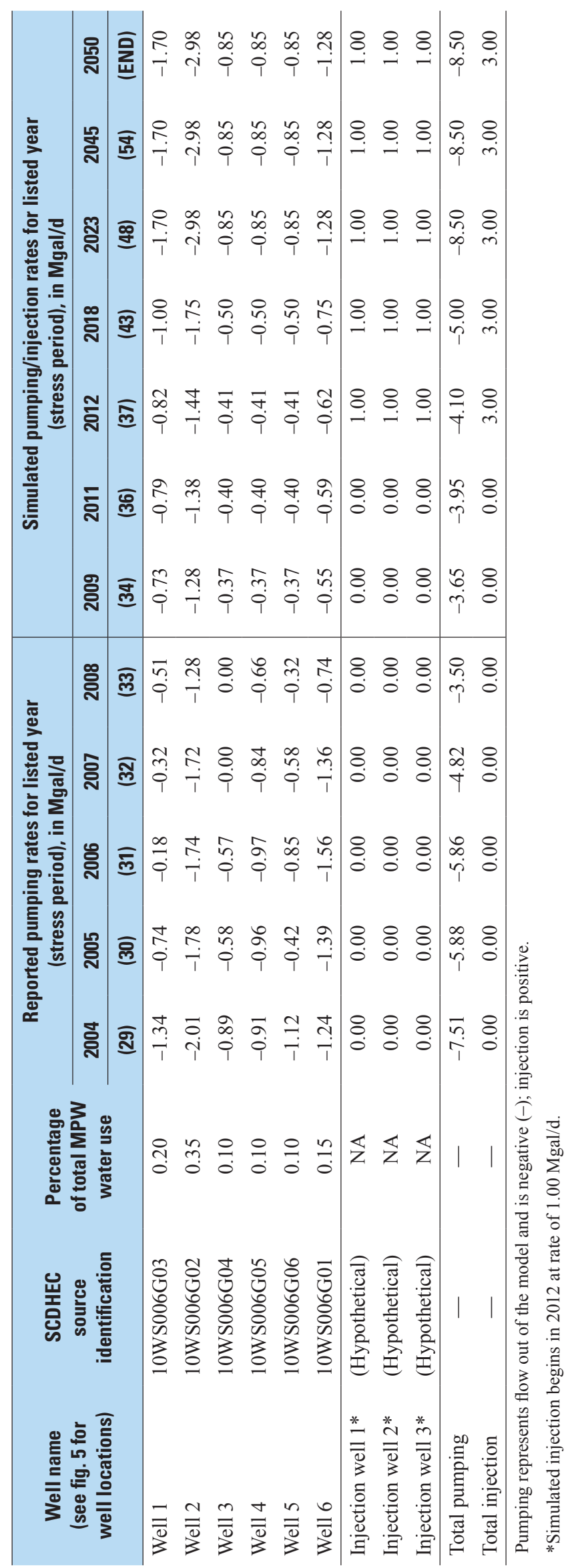




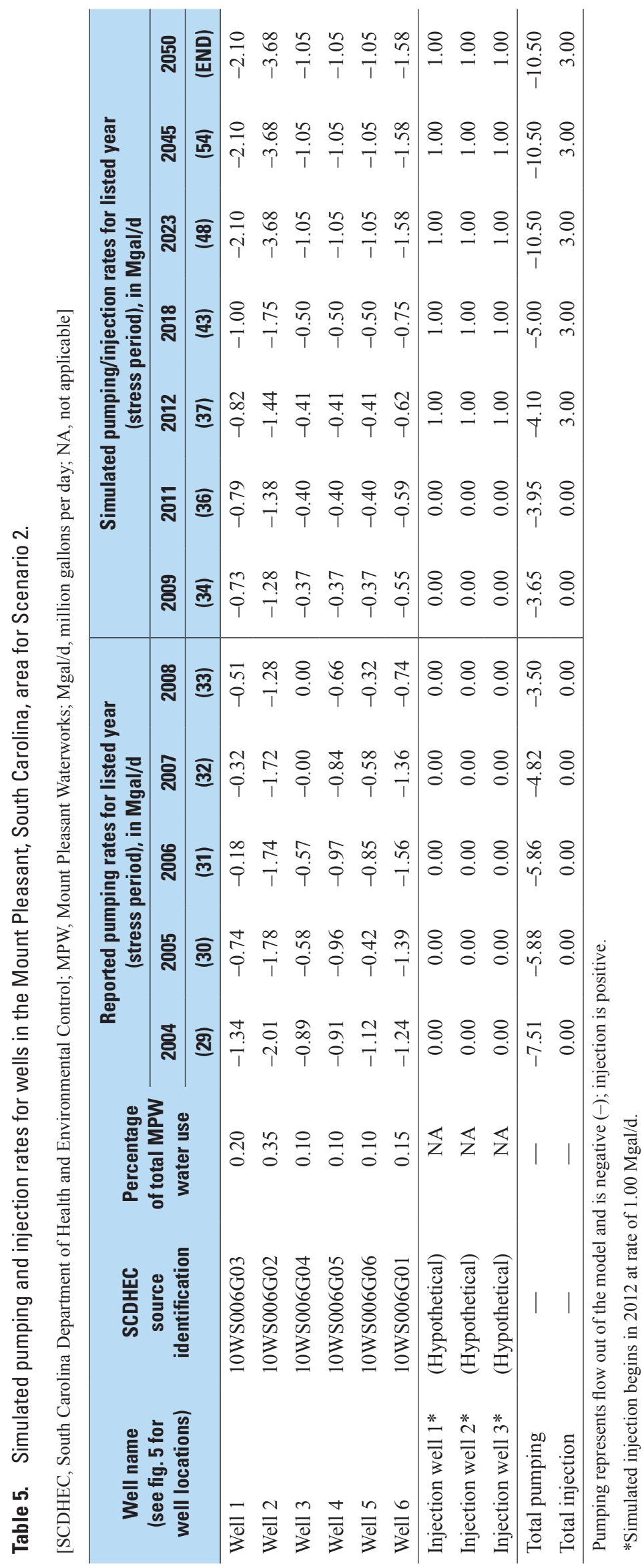


uniformly to $6.65,8.50$, and $10.5 \mathrm{Mgal} / \mathrm{d}$, for the Base Case and Scenarios 1 and 2, respectively. The 2023 MPW pumping rate was maintained through 2050 for all three simulations. The following scenarios were simulated to 2050:

- Base Case-Increase MPW pumping rates from that reported in 2008 to a maximum annual average rate equal to that reported for 2000-2004 (6.65 Mgal/d, table 3)

- Scenario 1-Moderate MPW groundwater use; increase MPW pumping rates from that reported in 2008 to a maximum annual average rate of $8.5 \mathrm{Mgal} / \mathrm{d}$; reclaimed water injection at $3 \mathrm{Mgal} / \mathrm{d}$ starting in 2012 (table 4)

- Scenario 2-Maximize MPW groundwater use; increase MPW pumping rates from that reported in 2008 to a maximum annual average rate of $10.5 \mathrm{Mgal} / \mathrm{d}$; reclaimed water injection at $3 \mathrm{Mgal} / \mathrm{d}$ starting in 2012 (table 5)

For Scenarios 1 and 2, injection began in the year 2012. Results of these scenarios, including estimated hydrographs, potentiometric surface maps, groundwater-level change maps, water budgets, and particle-tracking results, are described below. For each simulation, groundwater-level differences between the Base Case (2050) and the 2050 stress period were calculated for each production and injection well for comparison purposes (table 6). Particle-tracking simulations were completed for Scenario 2 only and represent the worst-case (fastest travel time) situation for the two injection scenarios because the higher simulated pumping would create the steepest head gradients and fastest transport times between injection and production wells.

\section{Base Case}

Results from the Base Case simulation represent a noninjection estimate of 2050 groundwater levels for comparison purposes for the two injection scenarios. The simulated 2050 potentiometric surface for the Mount Pleasant area (fig. 11) represents estimated groundwater levels for the Middendorf aquifer assuming future annual MPW pumping rates equal to average annual rates reported for 2000-2004 (6.65 Mgal/d). Maintaining these pumping rates caused a general decline of about $90 \mathrm{ft}$ in the simulated potentiometric surface of the Middendorf aquifer in the Mount Pleasant area (fig. 12). The greatest change in groundwater level $(-110 \mathrm{ft})$ occurred at Well 2 where simulated groundwater altitudes declined from $-238 \mathrm{ft}$ NGVD 29 during 2004 to $-348 \mathrm{ft}$ during 2050 (table 6). The relative difference in the simulated groundwaterlevel changes at the other five MPW wells was proportional to the percentage of total MPW pumping simulated at each well, proximity of that well to other MPW wells, and simulated hydraulic properties of the model cell where the production well is located. Simulated hydrographs for $\mathrm{CHN}-14$ and BRK-431 (figs. $13 A$ and $13 B$, respectively) illustrate the gradual decline in groundwater levels between 2004 and 2050 with overall changes of -93 and $-78 \mathrm{ft}$, respectively. Based on the Base Case simulation, an imaginary well located in the MPW well field (fig. 5) indicates that groundwater altitudes in the area will decline an estimated $75 \mathrm{ft}$ between 2004 and 2050 (fig. 13C).

Water budgets representing inflow and outflow of water for the model area concentrated at Mount Pleasant (fig. 5) are presented in figures 14 and 15 . These budgets represent a single stress period and show the inflow and outflow of

Table 6. Simulated 2050 groundwater altitudes and difference between Base Case and two scenarios in the Middendorf aquifer for the Mount Pleasant, South Carolina, area.

[ft NGVD 29, feet above or below (-) National Geodetic Vertical Datum of 1929; ft, feet]

\begin{tabular}{lccccc}
\hline $\begin{array}{c}\text { Well identification } \\
\text { (see fig. 5 for locations) }\end{array}$ & Simulated $\begin{array}{c}\text { 2050 groundwater altitude } \\
\text { (ft NGVD 29) }\end{array}$ & $\begin{array}{c}\text { Simulated difference in } \\
\text { 2050 groundwater altitudes } \\
\text { between Base Case and } \\
\text { scenarios (ft) }\end{array}$ \\
\cline { 2 - 6 } & Base Case & Scenario 1 & Scenario 2 & Scenario 1 & Scenario 2 \\
\hline Well 1 & -265 & -263 & -328 & 2 & -63 \\
Well 2 & -348 & -363 & -454 & -15 & -106 \\
Well 3 & -222 & -218 & -270 & 4 & -48 \\
Well 4 & -264 & -268 & -333 & -3 & -68 \\
Well 5 & -247 & -245 & -305 & 2 & -58 \\
Well 6 & -169 & -147 & -183 & 23 & -14 \\
\hline Injection well 1 (hypothetical) & -217 & -140 & -190 & 77 & 27 \\
Injection well 2 (hypothetical) & -159 & -109 & -143 & 50 & 16 \\
Injection well 3 (hypothetical) & -148 & -107 & -137 & 41 & 11 \\
\hline
\end{tabular}




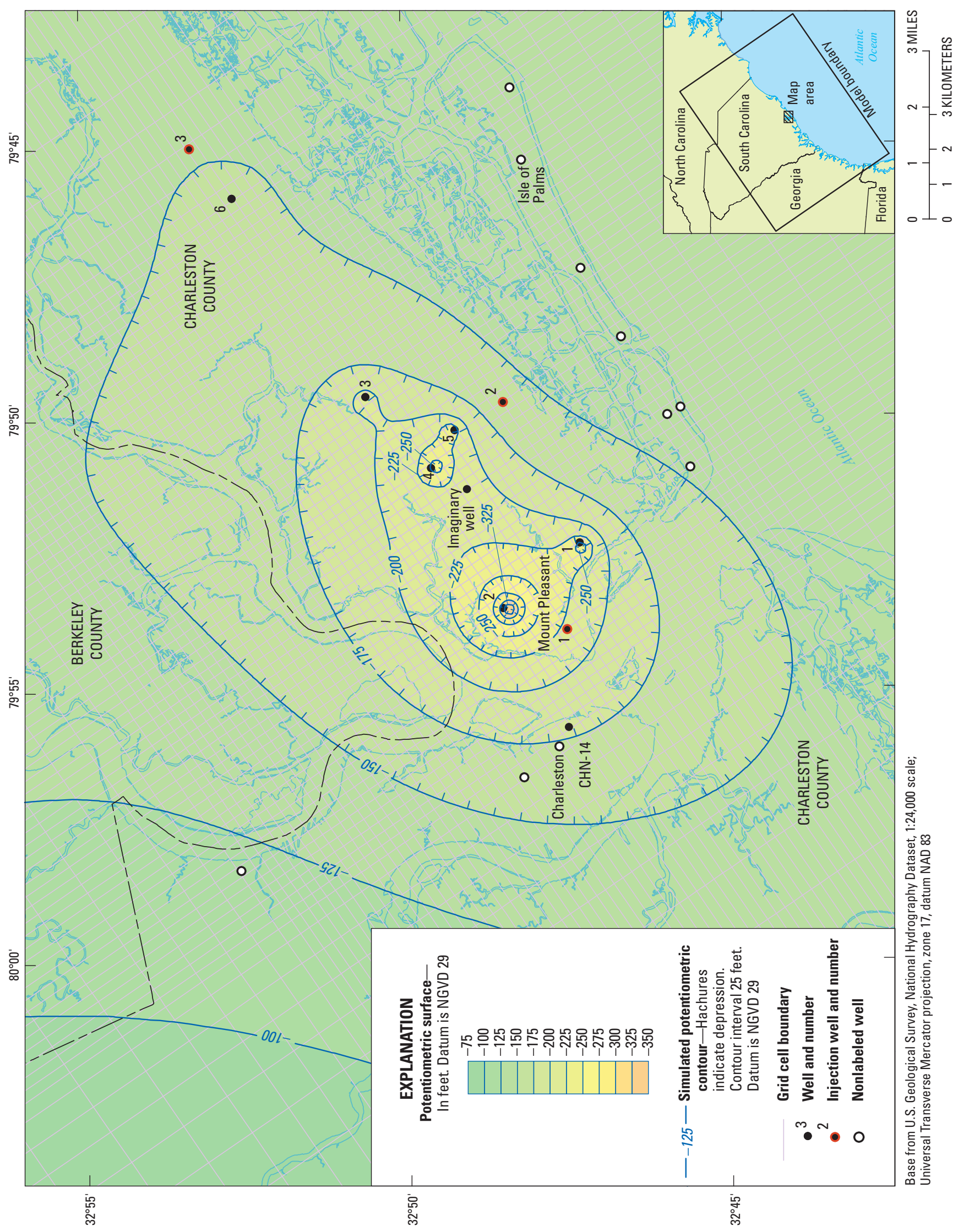

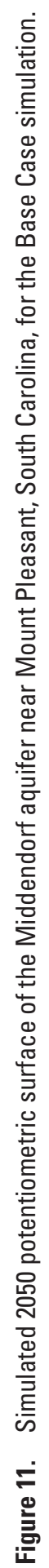




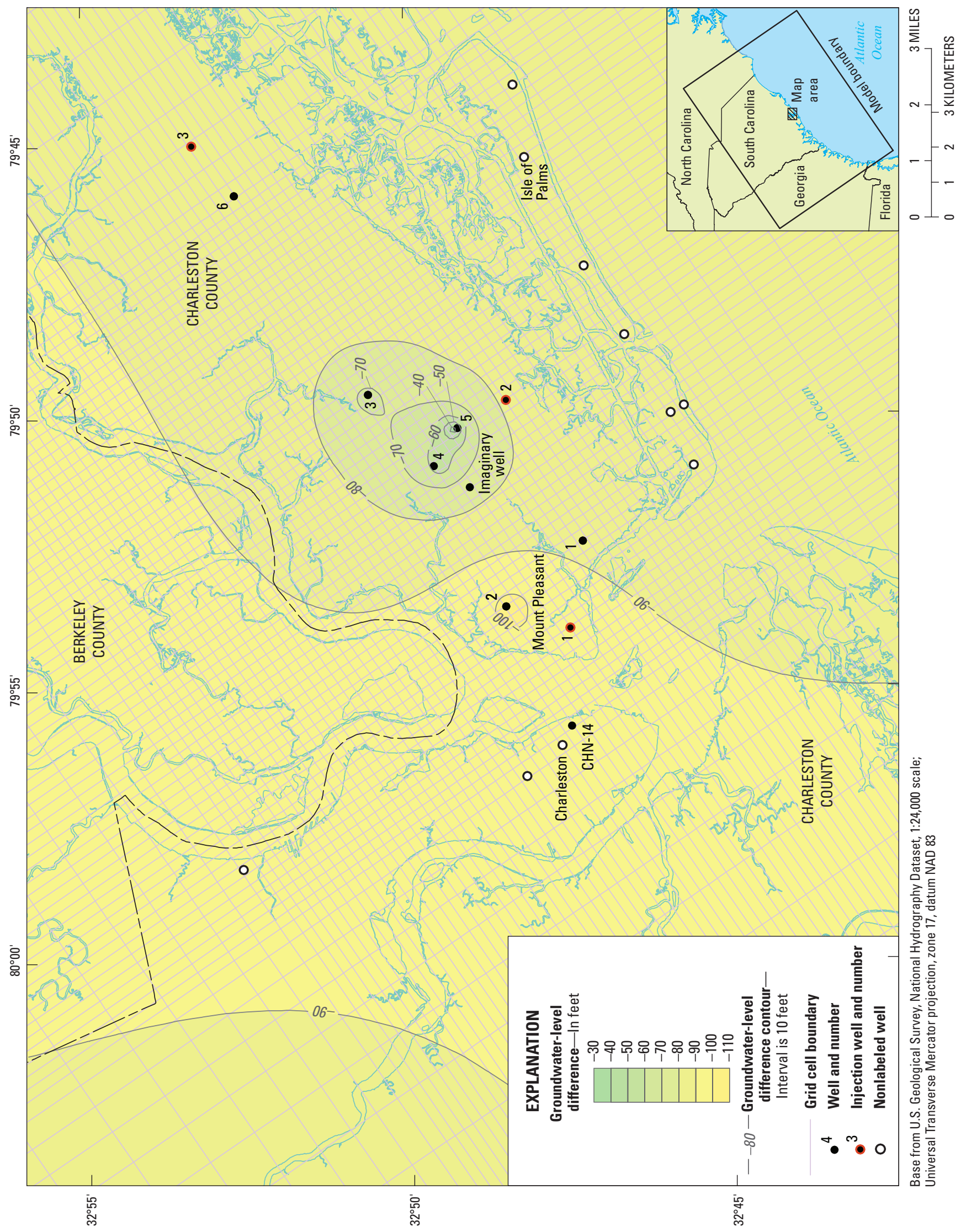

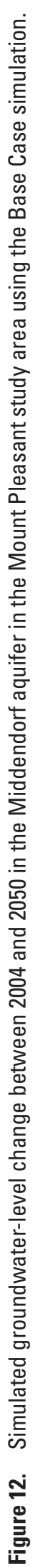




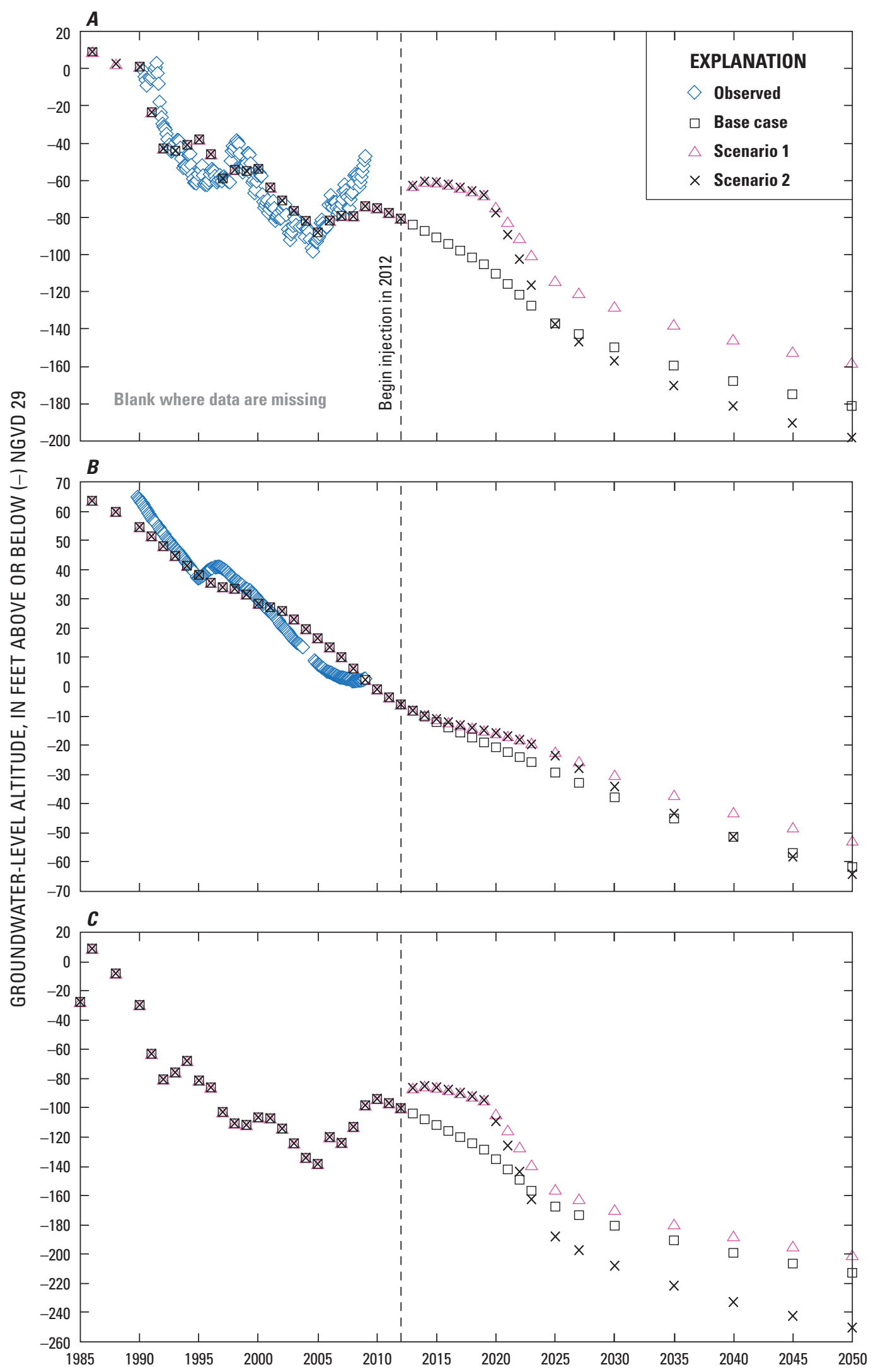

Figure 13. Simulated hydrographs from 1985 to 2050 for $(A) C H N-14$, (B) BRK- 431, and (C) an imaginary well for three model scenarios. 


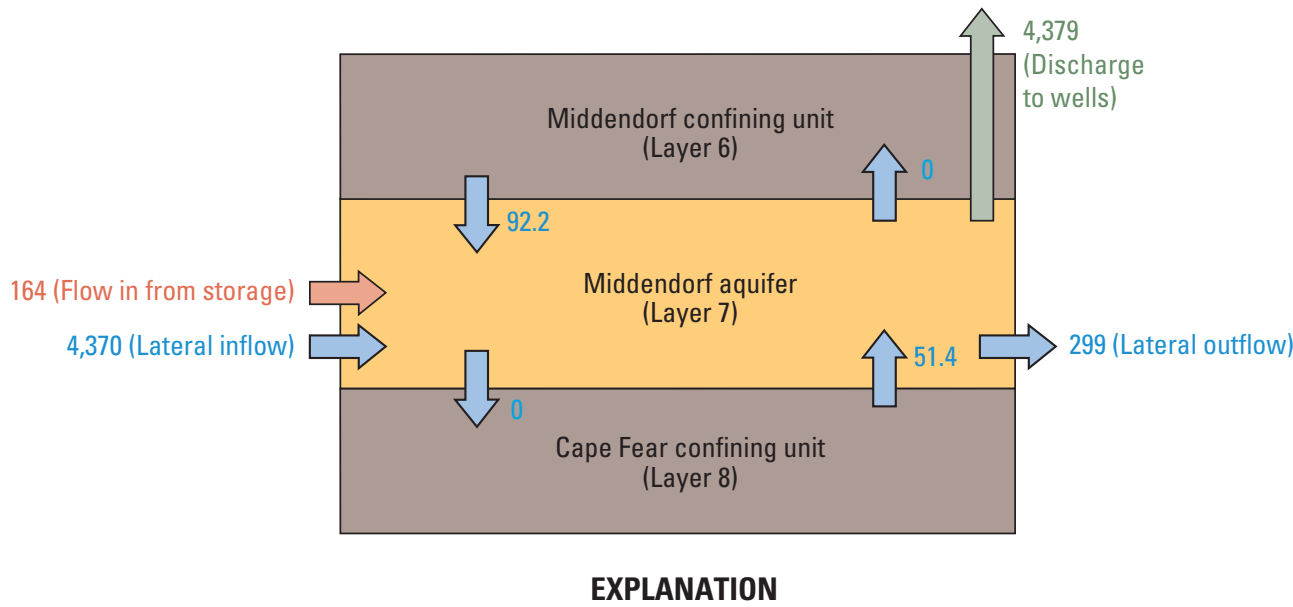

92.2 Flow direction and rate, in $\mathbf{1 , 0 0 0}$ gallons per day

Figure 14. Simulated water budget for 2011 for Base Case, Scenario 1, and Scenario 2.

groundwater to and from the Middendorf aquifer layer for each modeled hydrologic component. The water budgets include vertical flow to and from confining units, lateral flow into and out of the zone within the Middendorf aquifer, inflow through storage, and inflow and outflow through wells.

The water budget for 2011 (fig. 14) is equal for the Base Case, Scenario 1, and Scenario 2 because 2011 represents the year prior to injection in Scenarios 1 and 2 and, therefore, the stresses for all three simulations are the same. The largest flow component in the 2011 water budget for the Mount Pleasant area is discharge to wells at a rate of 4,379,000 gallons per day (gal/d). Additionally, 299,000 gal/d flows laterally out of this zone into the Middendorf aquifer due to the regional hydraulic gradient. Flow into this zone consists predominantly of lateral flow within the Middendorf aquifer at 4,370,000 gal/d. Additionally, $164,000 \mathrm{gal} / \mathrm{d}$ is released into this zone from storage.
Vertically, 92,200 gal/d flows down from the confining unit located above the Middendorf aquifer and 51,400 gal/d flows up from the confining unit below.

The largest flow component in the 2050 water budget for the Base Case is discharge to wells at a rate of $7,079,000 \mathrm{gal} / \mathrm{d}$ (fig. 15A). The production wells located within this zone include wells that are not owned by MPW, and therefore, the total withdrawal rate is greater than the $6.65 \mathrm{Mgal} / \mathrm{d}$ listed in table 3. Additionally, 175,000 gal/d flows laterally out of this zone into the Middendorf aquifer. Flow into this zone consists predominantly of lateral flow within the Middendorf aquifer at 6,957,000 gal/d. Additionally, $92,500 \mathrm{gal} / \mathrm{d}$ is released into this zone from storage. Vertically, $135,000 \mathrm{gal} / \mathrm{d}$ flows down from the confining unit located above the Middendorf aquifer and 69,100 gal/d flows up from the confining unit below. 

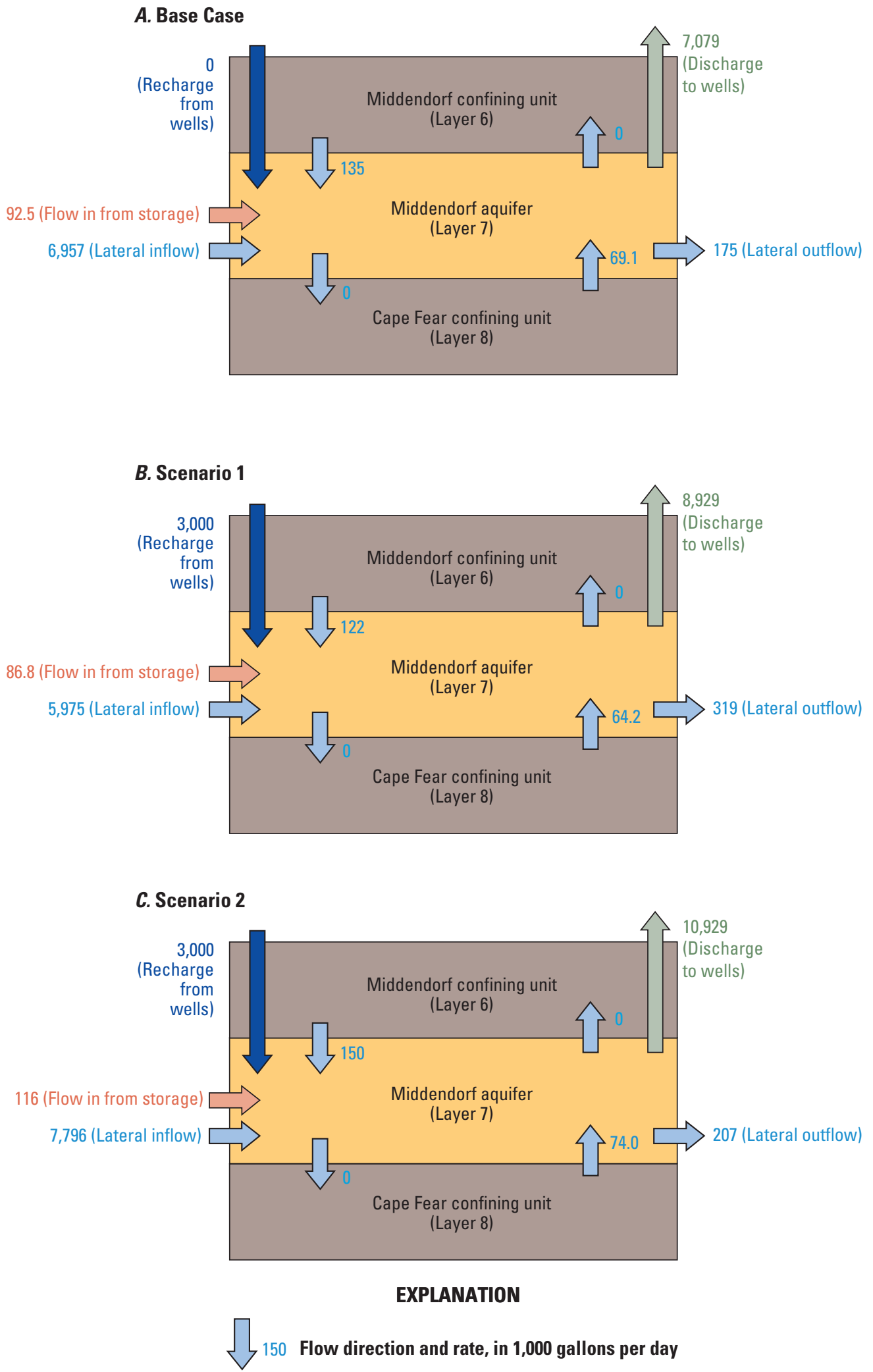

Figure 15. Simulated water budget for 2050 for (A) Base Case, (B) Scenario 1, and (C) Scenario 2. 


\section{Scenario 1}

Scenario 1 simulates moderate (up to a maximum annual average rate of $8.5 \mathrm{Mgal} / \mathrm{d}$ ) pumping from the MPW wells located in the Middendorf aquifer while injecting $3 \mathrm{Mgal} / \mathrm{d}$ in three hypothetical wells located in the Mount Pleasant area (fig. 5). Simulated groundwater altitudes for this scenario declined to $-363 \mathrm{ft}$ NGVD 29 in 2050 (fig. 16; table 6). The simulated injection created small injection mounds in the potentiometric surface for this scenario (fig. 16). Compared to the 2050 Base Case simulation, groundwater altitudes for Scenario 1 are between $15 \mathrm{ft}$ lower and $23 \mathrm{ft}$ higher at the Mount Pleasant Waterworks production wells and between 41 and $77 \mathrm{ft}$ higher at the injection wells (fig. 17; table 6). The greatest decrease in water level $(-15 \mathrm{ft})$ occurred at Well 2 where pumping was the greatest. For Scenario 1, simulated hydrographs for CHN-14, BRK-431, and the imaginary well show an initial recovery of groundwater altitudes in the Mount Pleasant area due to injecting this "bubble" of reclaimed water (2012-2014; fig. 13). From 2012 to 2025, groundwater altitudes at $\mathrm{CHN}-14$ and the imaginary well are between 11 and $37 \mathrm{ft}$ higher for the Scenario 1 simulation compared to the Base Case simulation (figs. 13A, C). As MPW pumping increases over time, however, these higher groundwater levels decline, but are still higher than the Base Case. Simulated hydrographs for CHN-14, BRK-431, and the imaginary well show higher groundwater levels in 2050 for Scenario 1, even though total MPW pumping is greater for Scenario 1 (8.50 Mgal/d) compared to the Base Case $(6.65 \mathrm{Mgal} / \mathrm{d}$; fig. 13). Hence, injecting $3 \mathrm{Mgal} / \mathrm{d}$ of reclaimed water into the Middendorf aquifer more than compensates for the $1.85 \mathrm{Mgal} / \mathrm{d}$ higher pumping rate for Scenario 1. While the general decline in groundwater levels are still present for these wells, 2050 groundwater altitudes are between 9 and $23 \mathrm{ft}$ higher for Scenario 1 than the Base Case (fig. 13).

The largest flow component in the 2050 water budget for Scenario 1 is discharge to wells at a rate of $8,929,000 \mathrm{gal} / \mathrm{d}$ (fig. 15B). The production wells located in the Mount Pleasant study area include wells that are not owned by MPW, and therefore, the total withdrawal rate is greater than the $8.50 \mathrm{Mgal} / \mathrm{d}$ listed in table 4. Additionally, 319,000 gal/d flows laterally out of this zone into the Middendorf aquifer due to the regional hydraulic gradient. Flow into this zone consists predominantly of 5,975,000 gal/d of lateral flow within the Middendorf aquifer. Three million gallons of water were injected into this zone through the hypothetical injection wells (fig. 5). Additionally, 86,800 gal/d was released into this zone from storage. Vertically, 122,000 gal/d flows down from the confining unit located above the Middendorf aquifer and $64,200 \mathrm{gal} / \mathrm{d}$ flows up from the confining unit below.

\section{Scenario 2}

Scenario 2 simulates maximum capacity pumping (up to a maximum annual average rate of $10.5 \mathrm{Mgal} / \mathrm{d}$ ) for the MPW network of production wells while injecting $3 \mathrm{Mgal} / \mathrm{d}$ in the three hypothetical wells located in the Mount Pleasant area (fig. 5). Simulated groundwater altitudes declined to $-454 \mathrm{ft}$ NGVD 29 in 2050 (fig. 18; table 6). Injection mounds in the potentiometric surface are less pronounced for Scenario 2 compared to Scenario 1 because of the higher pumping rates simulated for Scenario 2 (figs. 16, 18). Compared to the 2050 Base Case simulation, groundwater altitudes for Scenario 2 are between 14 and $106 \mathrm{ft}$ lower at the MPW production wells and between 11 and $27 \mathrm{ft}$ higher at the injection wells (fig. 19; table 6). The greatest decrease in water level (-106 ft) occurred at Well 2 where pumping was the greatest. For Scenario 2, simulated hydrographs for CHN-14, BRK-431, and the imaginary well show an initial recovery of groundwater altitudes in the Mount Pleasant area due to injection (2012-2014; fig. 13). From 2012 to 2022, groundwater altitudes at CHN-14 and the imaginary well are between 5 and $37 \mathrm{ft}$ higher for the Scenario 2 simulation compared to the Base Case simulation (figs. $13 \mathrm{~A}, \mathrm{C}$ ). As the withdrawal rates are increased to $10.5 \mathrm{Mgal} / \mathrm{d}$, however, the hydrographs drop to altitudes between 2 and $38 \mathrm{ft}$ lower that those simulated for the Base Case (fig. 13).

The largest flow component in the 2050 water budget for Scenario 2 is discharge to wells at a rate of 10,929,000 gal/d (fig. 15C). The production wells located within the Mount Pleasant study area include wells that are not owned by MPW, and therefore, the total withdrawal rate is greater than the $10.50 \mathrm{Mgal} / \mathrm{d}$ listed in table 5. Additionally, 207,000 gal/d flows laterally out of this zone into the Middendorf aquifer due to the regional hydraulic gradient. Flow into this zone consists predominantly of 7,796,000 gal/d of lateral flow within the Middendorf aquifer. Three million gallons of water were injected into this zone through the hypothetical injection wells (fig. 5). Additionally, 116,000 gal/d was released into this zone from storage. Vertically, 150,000 gal/d flows down from the confining unit located above the Middendorf aquifer and 74,000 gal/d flows up from the confining unit below.

\section{Particle-Tracking Analysis}

Particle tracking can be used to simulate the path an imaginary particle of water follows through a simulated groundwater-flow system and the distance, velocity, and time of travel along this path. Particle tracking was simulated using version 4.2 of MODPATH (Pollock, 1994) within a commercial graphical user interface using output from the transient MODFLOW groundwater-flow model. MODPATH was used to compute three-dimensional flow directions and time of travel using imaginary particles.

Particle-tracking simulations were completed for Scenario 2 only and represent the worst-case (fastest travel time) situation for the two injection scenarios because the higher simulated pumping would create the steepest head gradients and fastest transport times between injection and production wells. The approach used was to release four imaginary water particles within the Middendorf aquifer at the model cells 


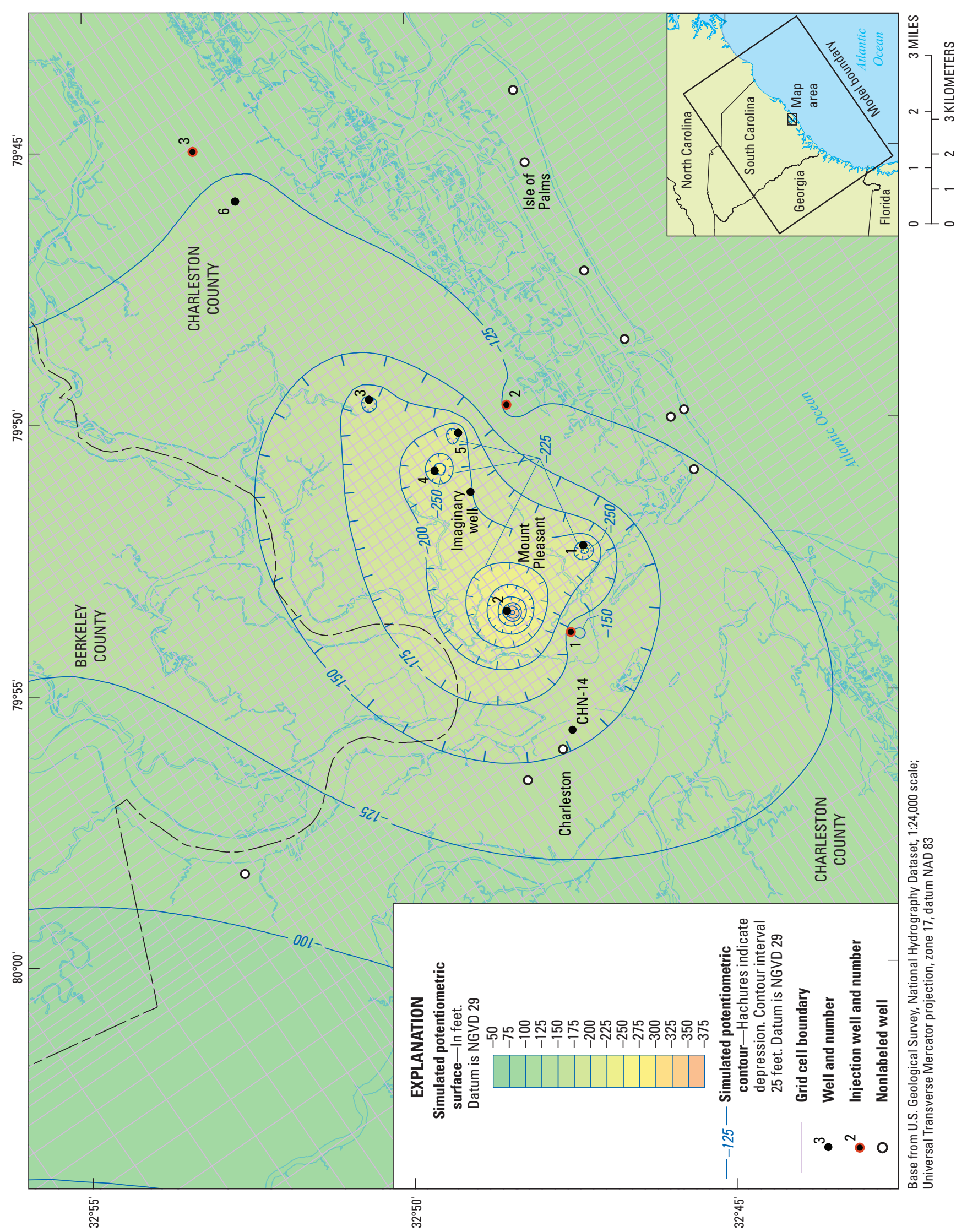

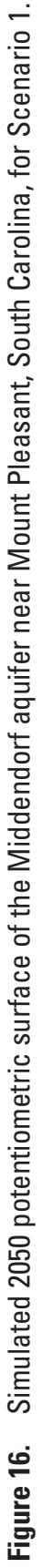




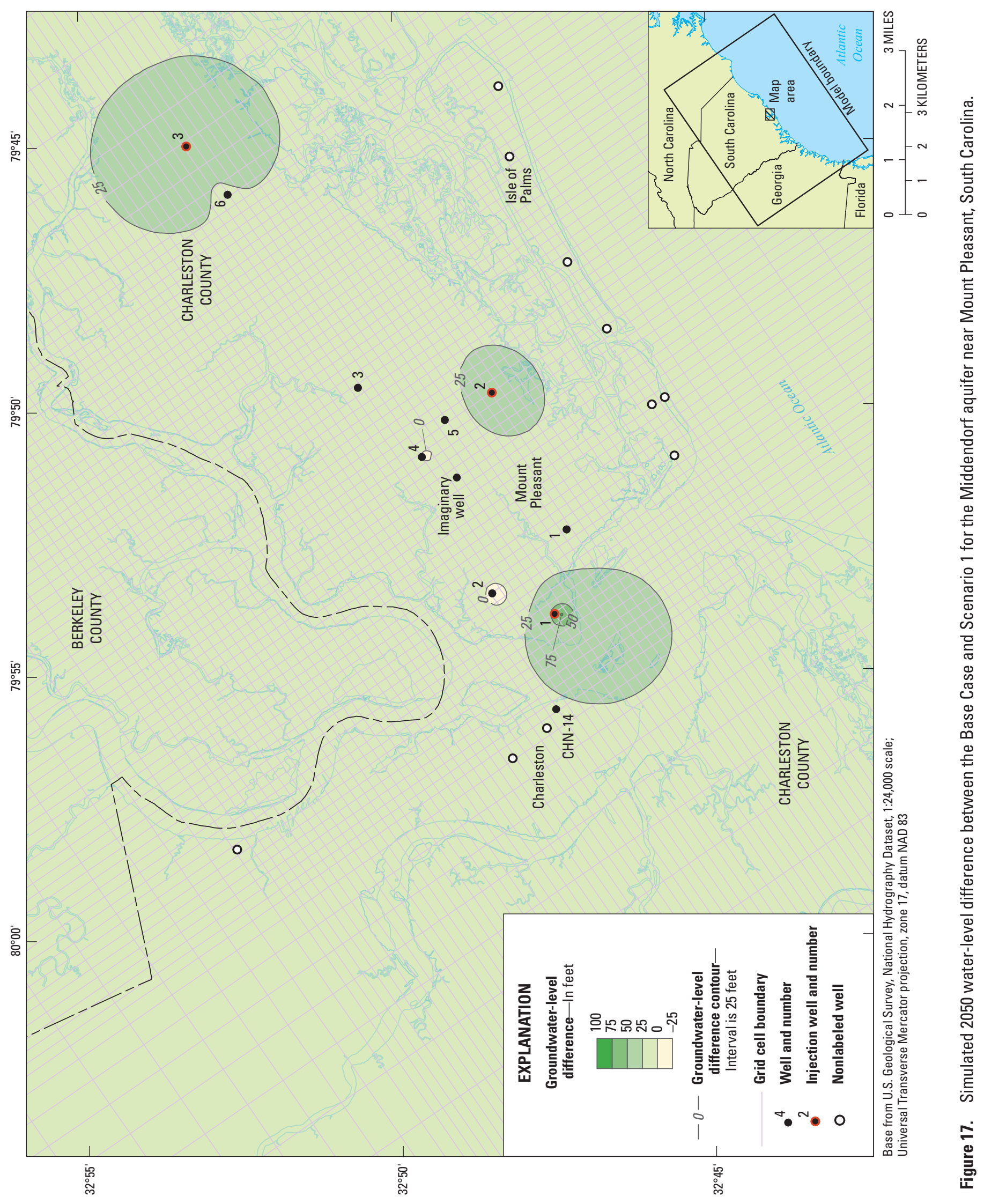




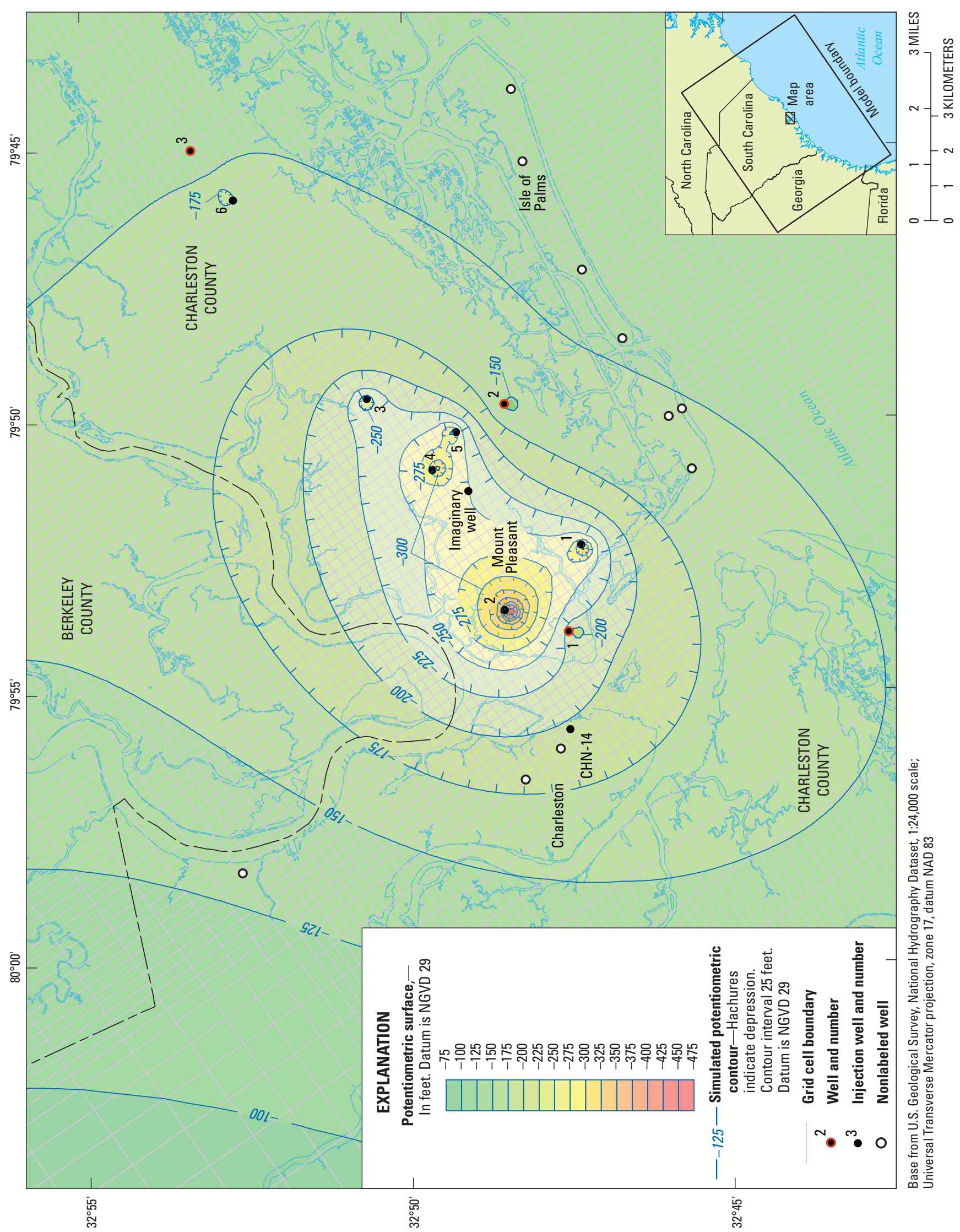

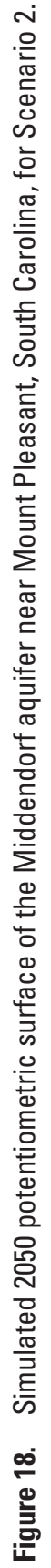




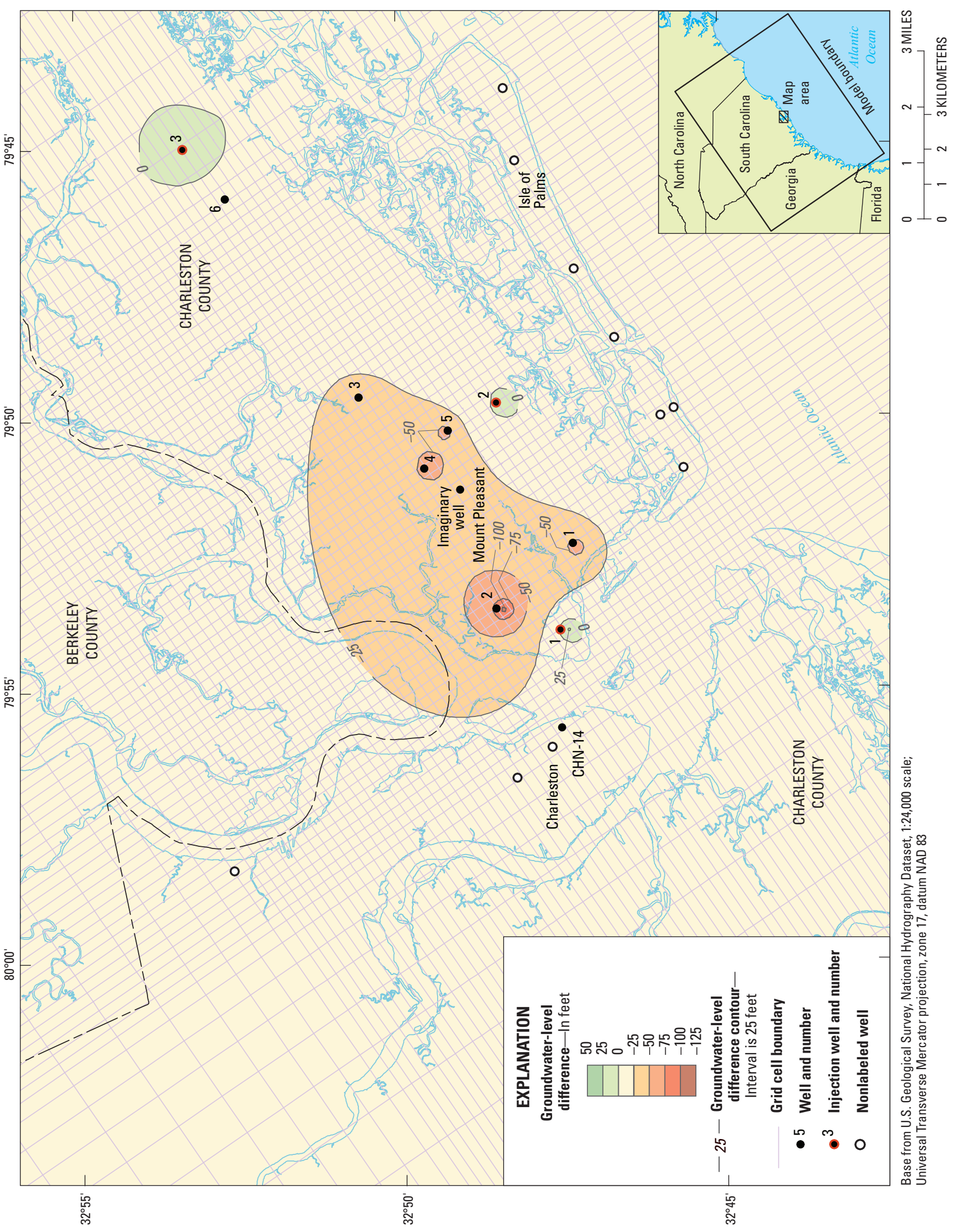

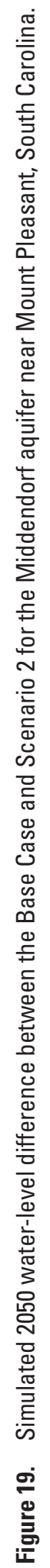


of the three proposed injection well locations in the year 2012 and track them through time until they encountered a discharge point within the simulated flow field. In this case, the discharge points are the MPW production wells, and time of travel for a given particle ends when that particle reaches the cell boundary where a production well is simulated. Flow directions and time of travel were calculated for the particles. Injecting water produced a mounding effect as the injected water moved away from the well and resulted in both direct and circuitous particle routes. The slow time of travel associated with some of the particles necessitated extending the total simulation time of the model beyond 2050. For simulated time periods after 2050, pumping rates for all modeled wells were maintained at the same rates as used for 2050 .

Particle-tracking simulations generally are sensitive to horizontal hydraulic conductivities, model cell sizes, and effective porosities. Aquifer test results for the Middendorf aquifer are available in the MPW well field, and the model grid specified is $1,000 \mathrm{ft}$ by $1,000 \mathrm{ft}$ for most of the well field, except for production well 6 and injection well 3, which are in slightly larger model cells (fig. 5). There are no published values, however, for porosity for the Middendorf aquifer in the Mount Pleasant area. Heath (1983) gives selected values of porosity for various geologic materials, including a value of 25 percent for sand. The Middendorf aquifer is composed of three sand intervals with clay interbeds. To account for the uncertainty of the porosity values within the Middendorf aquifer, two sets of particle-tracking scenarios were developed using uniform values of 20 and 30 percent porosity. Generally, lower porosity values produce faster particle times of travel than higher porosity values.

Because MODPATH particles cannot be placed exactly at the location of each proposed injection well and because the time of travel ends when a particle reaches the cell boundary of a production well, particle-tracking results may over- or underestimate times-of-travel estimates depending on the locations of these wells within the model cells. Production wells typically are not located at the endpoints of the cell boundaries and may be near the opposite side of the cell, thus causing an underestimation of the time of travel. This problem is sometimes offset or exacerbated by the location of the injection well within a model cell. Simulations where the injection wells are located closer to the production well than the starting points of the particles may overestimate the time of travel. Simulations where the injection wells are located at greater distances from the production well than the starting points of the particles may underestimate the time of travel. In general, particle tracking for this investigation should be used for estimates of approximate time of travel.

Times of travel and flow paths were calculated for the four imaginary particles released at each of the three injection wells using a porosity of 20 percent (figs. 5, 20; table 7).

Distances listed in table 7 represent the approximate "straightline" distance between the injection wells and production wells, and do not represent the simulated distance traveled by particles. The times of travel simulated using the 20 percent porosity varied from 18 to 179 years with particles released at injection well 1 having the fastest average time of travel (39 years; table 7) and particles released at injection well 2 having the slowest average time of travel (89 years; table 7). The four particles released at injection well 1 moved toward MPW production well 2 and ended at the model cell that contains the production well (fig. 20A). These times of travel may be slightly underestimated due to location of production well 2 within the 1,000 by $1,000 \mathrm{ft}$ model cell. The fastest time of travel of the four particles is 25 years, and the slowest time is 54 years (table 7). The four particles released at injection well 2 moved to MPW production wells 4 and 5 (fig. 20B). The fastest time of travel was 37 years for a particle that discharged to MPW production well 5. The slowest time of travel was 179 years for a particle that discharged to MPW production well 4 (table 7). The times of travel for particles discharging to production well 4 are slightly underestimated because of the production well location within the model cell.
Table 7. Summary of simulated times of travel for Scenario 2 for conditions of two porosities and distances between injection wells and nearest downgradient production well, Mount Pleasant area model, South Carolina.

[Four particles were assigned to each injection-well cell in the year 2012; particle index is an arbitrarily assigned name for particles at each injection well]

\begin{tabular}{|c|c|c|c|c|}
\hline \multirow{2}{*}{$\begin{array}{l}\text { Injection } \\
\text { well }\end{array}$} & \multirow{2}{*}{$\begin{array}{l}\text { Particle } \\
\text { index }\end{array}$} & \multicolumn{2}{|c|}{$\begin{array}{c}\text { Simulated time of travel, } \\
\text { in years }\end{array}$} & \multirow{2}{*}{$\begin{array}{c}\text { Distance between } \\
\text { injection well and } \\
\text { nearest downgradient } \\
\text { production well, in feet }\end{array}$} \\
\hline & & $20 \%$ porosity & $30 \%$ porosity & \\
\hline \multirow{5}{*}{1} & $1 \mathrm{a}$ & 26 & 37 & 6,300 \\
\hline & $1 b$ & 25 & 36 & 6,300 \\
\hline & $1 \mathrm{c}$ & 54 & 76 & 6,300 \\
\hline & $1 d$ & 52 & 73 & 6,300 \\
\hline & Average & 39 & 56 & 6,300 \\
\hline \multirow{5}{*}{2} & $2 \mathrm{a}$ & 51 & 72 & 5,300 \\
\hline & $2 b$ & 37 & 54 & 5,300 \\
\hline & $2 \mathrm{c}$ & 89 & 126 & 9,200 \\
\hline & $2 d$ & 179 & 256 & 9,200 \\
\hline & Average & 89 & 127 & 7,250 \\
\hline \multirow{5}{*}{3} & $3 a$ & 123 & 156 & 6,100 \\
\hline & $3 b$ & 53 & 72 & 6,100 \\
\hline & $3 c$ & 18 & 25 & 6,100 \\
\hline & $3 d$ & 42 & 59 & 6,100 \\
\hline & Average & 59 & 78 & 6,100 \\
\hline
\end{tabular}




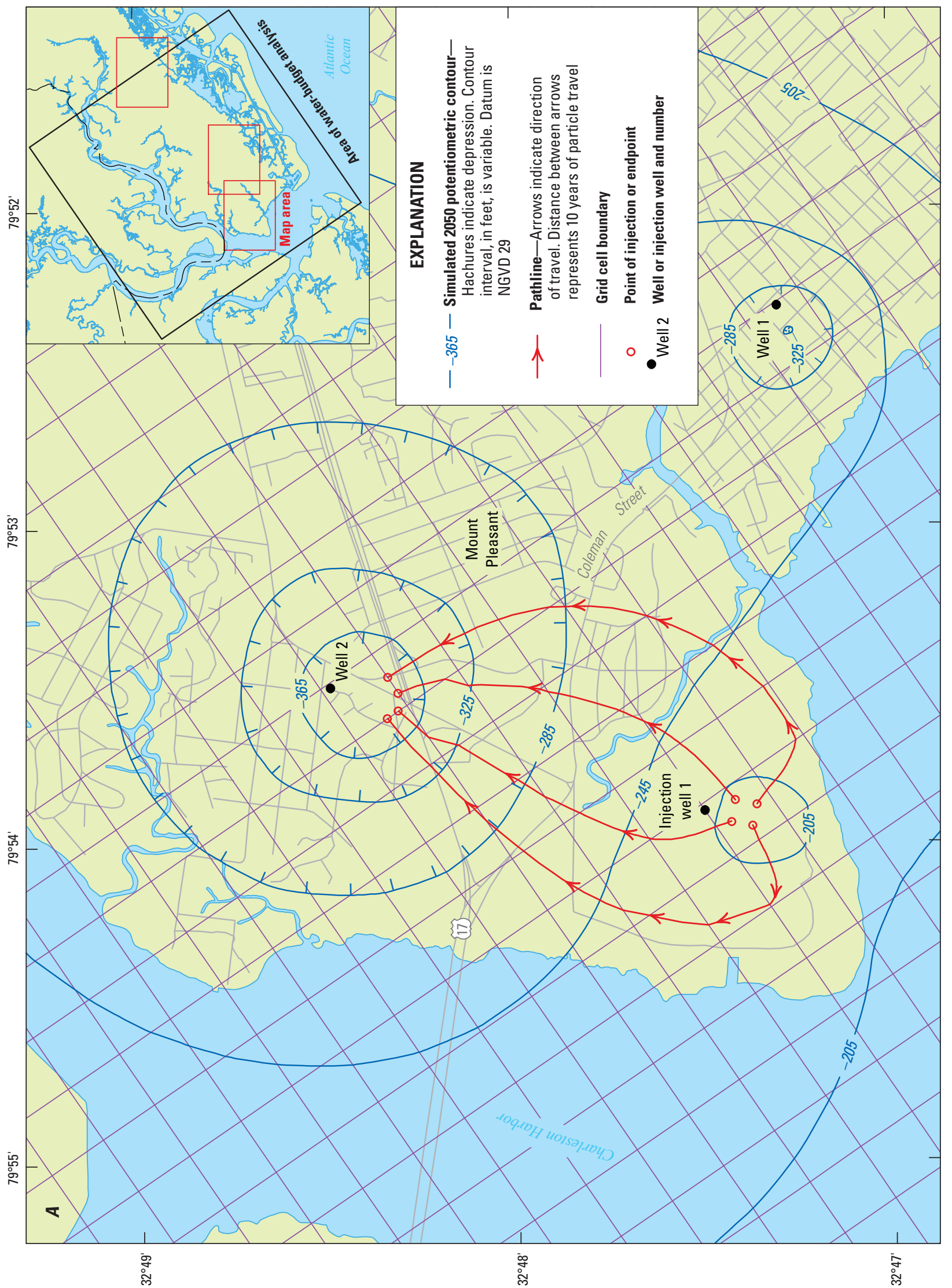

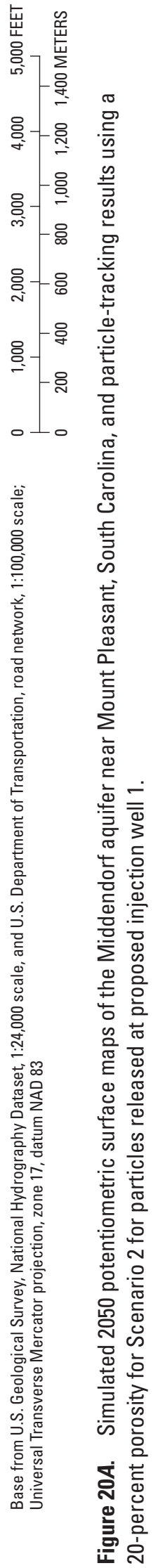




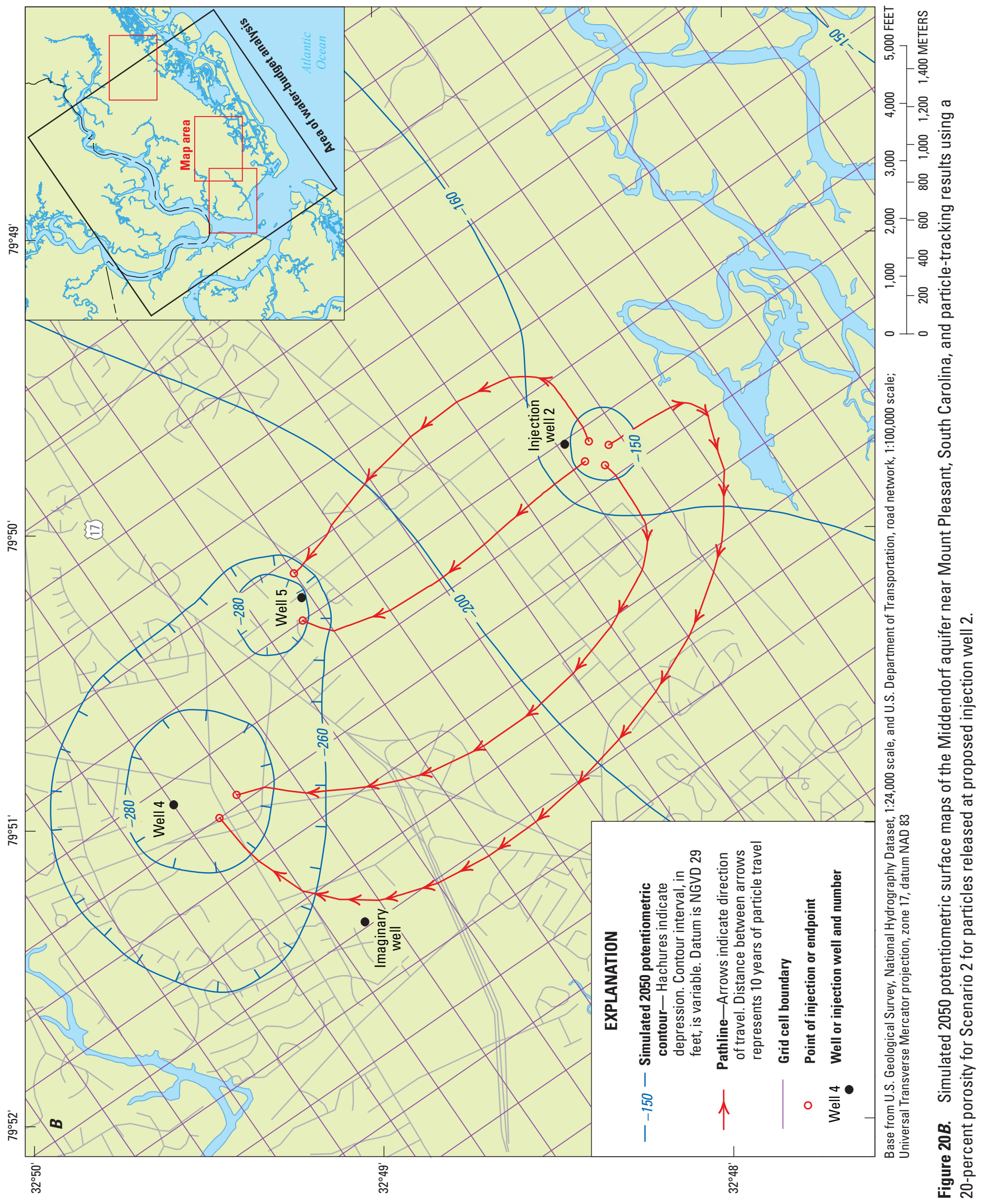




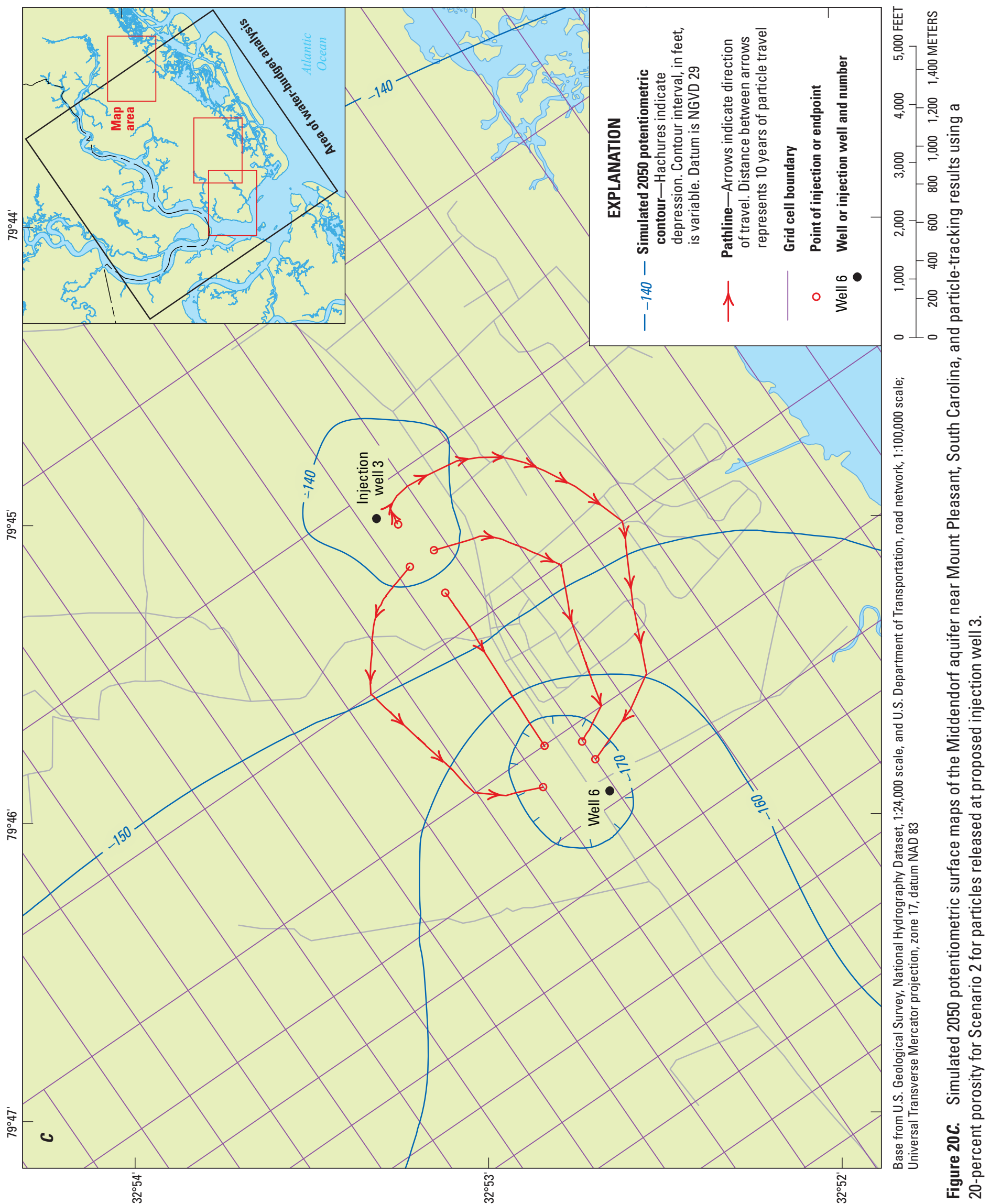


The four particles released at injection well 3 all discharged at MPW production well 6 (fig. 20C). The fastest time of travel was 18 years and the slowest was 123 years (table 7). The fastest time of travel was underestimated because of the location of the particle starting point in the injection cell. The model cell that contains injection well 3 is 1,000 by $3,000 \mathrm{ft}$ (fig. 5), and the particle with the fastest travel time is released closer to MPW production well 6 than the actual injection well, which results in a faster travel time.

Times of travel and flow paths were calculated for the four imaginary particles released at each of the three injection wells using a porosity of 30 percent (figs. 5, 21). The times of travel varied from 25 to 256 years, with particles released at injection well 1 having the fastest average time of travel (56 years; table 7) and particles released at injection well 2 having the slowest average time of travel (127 years; table 7). The four particles released at injection well 1 all moved toward MPW production well 2 (fig. 21A). The fastest time of travel was 36 years, and the slowest time of travel was 76 years (table 7 ). These travel times are slightly underestimated because of the location of production well 2 within the 1,000 by $1,000-\mathrm{ft}$ model cell. The four particles released at injection well 2 moved toward and discharged to MPW production wells 4 and 5 (fig. 21B). The fastest time of travel was 54 years for a particle that moved to MPW production well 5. The slowest time of travel was 256 years for a particle that discharged at MPW production well 4 . The times of travel to MPW production well 4 are slightly underestimated because of the location of the production well in the model cell. The four particles released at injection well 3 moved toward and discharged to MPW production well 6 (fig. 21C). The fastest time of travel was 25 years, and the slowest time of travel was 156 years (table 7). The fastest time of travel was underestimated because of the location of the particle starting point in the injection cell. The model cell that contains injection well 3 is 1,000 by $3,000 \mathrm{ft}$ (fig. 5), and the particle with the fastest travel time was released closer to MPW production well 6 than the actual injection well, which results in a faster travel time.

\section{Model Limitations}

Groundwater models are simplified numerical approximations of actual groundwater-flow systems. The many assumptions incorporated in the development of the model result in limitations to the accuracy of the model and ability of the simulated system to predict actual hydraulic conditions at any given point in the model over time. Factors that could affect the reliability of the model include model scale, the method of stratifying the model into layers, the accuracy and method of distributing the available hydraulic data, the location of and method of simulating aquifer boundaries, and methods of simulating recharge and base flow in rivers.

The flow model was calibrated to simulate regional groundwater flow throughout the study area. The model uses a variably spaced grid with the best resolution located at Mount Pleasant, SC, where the minimum cell size is 1,000 by $1,000 \mathrm{ft}$. Elsewhere, the model cell sizes are as large as 10,000 by $10,000 \mathrm{ft}$. The size of the larger cells limits the ability of the model to accurately simulate local conditions such as discharge to wells or rivers in those areas.

Lack of knowledge of the altitude and configuration of the water-table altitude within the surficial aquifer is an additional limitation of the model. Knowledge of these altitudes would result in a more accurate simulation of the specified-head boundary within the surficial aquifer.

The flow model was developed by interpolating data from 96 boreholes into nine continuous layers throughout the study area. Interpolation in areas of limited data or extrapolation of the layers to the model boundaries may produce undesired results, such as inappropriately thinning or thickening of units.

Hydraulic data incorporated in the model include horizontal hydraulic conductivity values that were approximated using reported transmissivity values and reported and assumed aquifer thicknesses. Horizontal hydraulic conductivity values also were estimated during model calibration and recalibration where actual values were absent. Incorporation of hydraulic conductivity values in the model is further complicated by allowing the measured values to vary up to a factor of 5 during the model calibration process. The absence of reliable horizontal hydraulic conductivity data for the confining units limits the overall accuracy of the model. The calibrated distribution of hydraulic conductivity is a large-scale approximation of measured and estimated values; the calibrated results should be considered approximate estimates only.

Water-use data incorporated in the model probably underrepresent the actual historic water use. Specifically, water-use data from the SCDHEC include only those wells that pump at a rate that exceeds $3 \mathrm{Mgal}$ per month. Historic water use is more uncertain for the earliest years of pumping and more reliable for recent water-use years. In addition, water use was assigned to specific aquifers when the aquifer was designated by the water-use provider or when the aquifer could be ascertained from well construction information and interpolated model layering. Water-use data were not used from wells for which well construction information was not available.

Assumptions regarding type and location of model boundaries affect the reliability of the model. Model boundaries for this study were chosen to be similar to the boundaries of previous models of the South Carolina Coastal Plain. In general, model boundaries were placed at natural hydraulic boundaries or at distances far enough from the primary area of focus (Mount Pleasant) so that the choice of boundary did not greatly affect the simulated groundwater levels in Mount Pleasant, SC. Care should be taken when evaluating predicted simulated results outside of this area of focus.

Recharge rates used in the model are net recharge only. Rainfall runoff and evapotranspiration are not directly simulated in the model, and the six precipitation stations used in the model represent a small fraction of the large area in the model where recharge is simulated. The precipitation data 


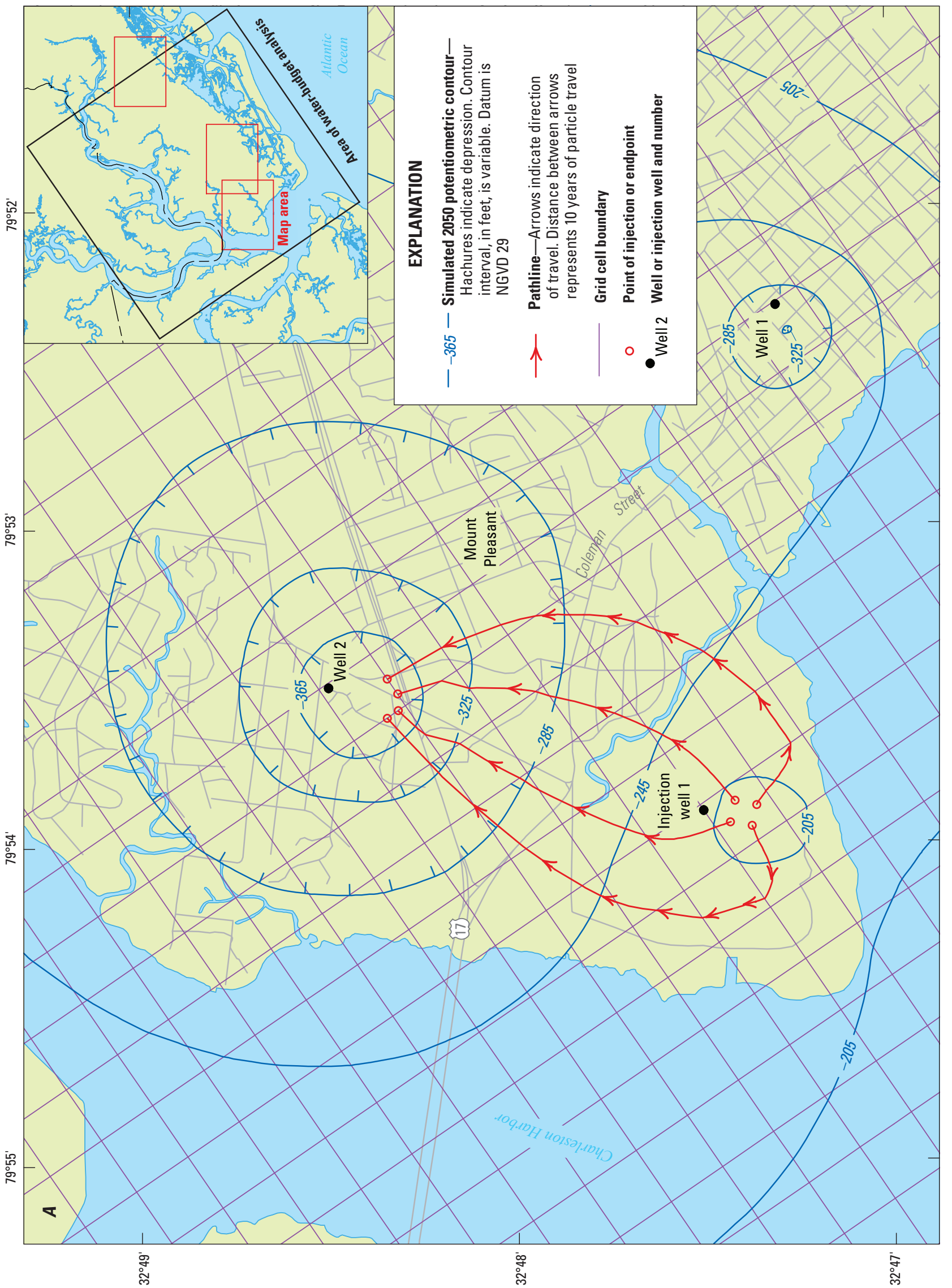

点

宊-空

$-\frac{5}{5}$

总

언-응

은

- 오

- 10 을

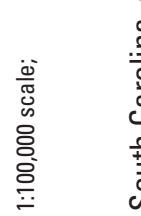

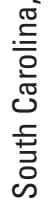

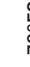




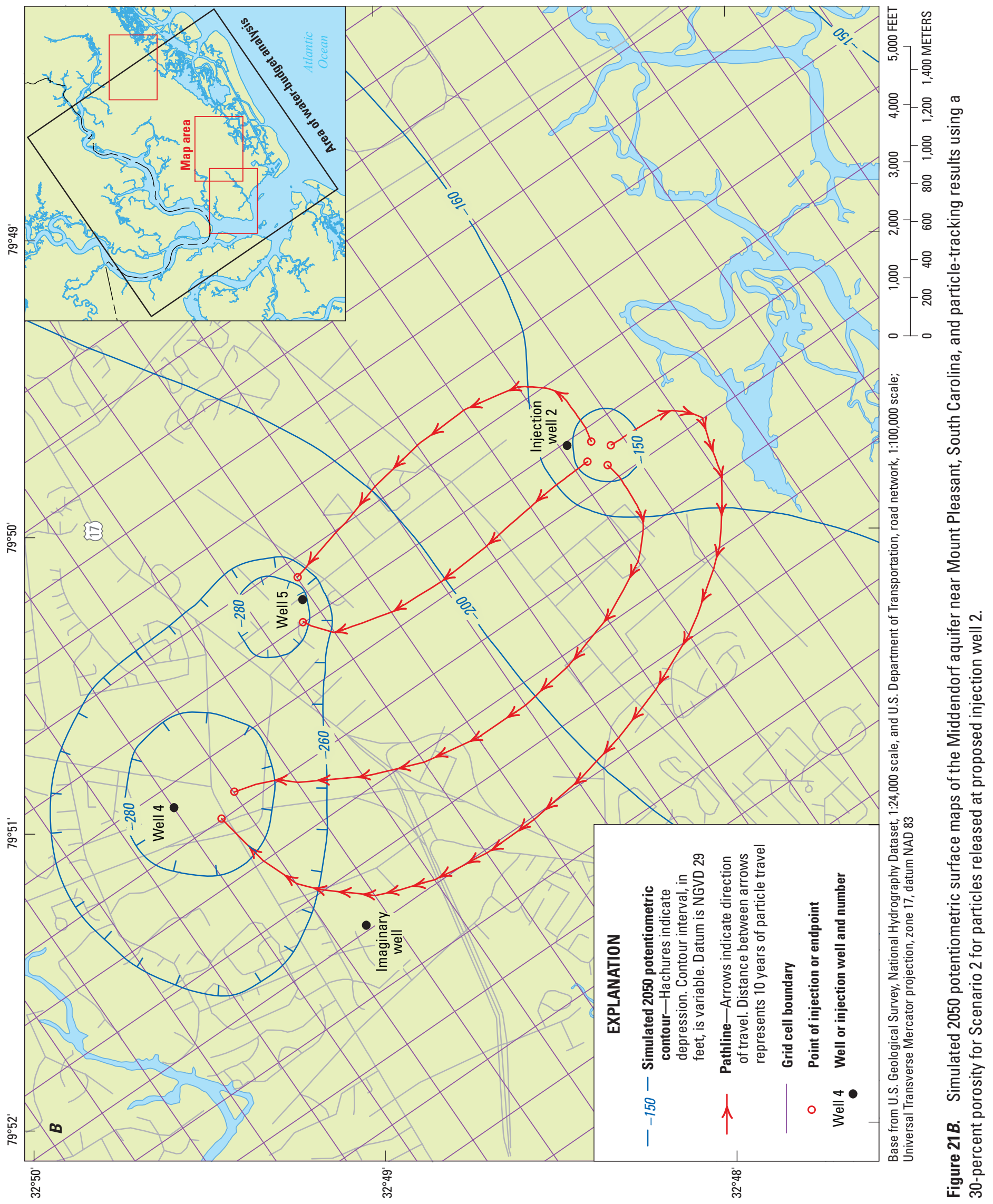




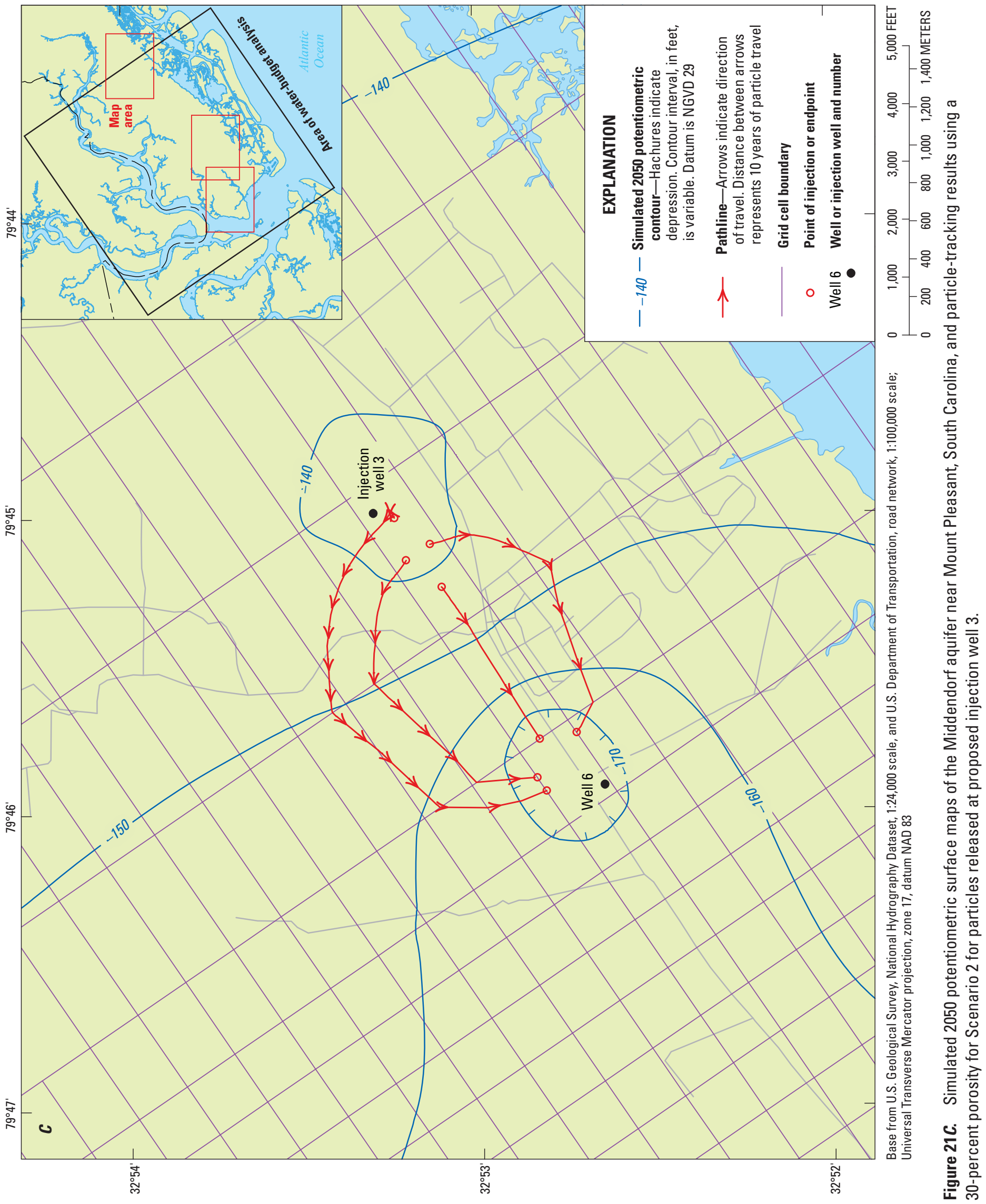


used to estimate the net recharge rates and net recharge rate variability were collected over a 107 -year period and are, most likely, subject to an unknown degree of uncertainty.

The analysis of stream base-flow data represents only an approximation of actual groundwater base flow. Daily streamflow data from 17 stations located in the upper Coastal Plain of North and South Carolina were used in the model. The periods of record available for analysis varied substantially for each station. Streambed conductance values simulated in the model are derived from model calibration, as there are no published values or field measurements of streambed conductance available for the study area.

Lateral and vertical head gradients and hydraulic properties are the important factors that control particle tracking using MODPATH. Data for these hydraulic properties for the Middendorf aquifer in the Mount Pleasant area are sparse, and there are no published estimates of porosity or vertical hydraulic conductivity for the aquifer. The model cell size affects the times of travel of the particles and can cause the times to be over- or underestimated depending on the location of the injection or production wells within the cells.

The calibrated model is one representation of the study area over the time period simulated, and similar results could be achieved through different grid discretizations, model boundary types or locations, and interpolation of model layering or hydraulic properties. However, the calibrated model is considered a reasonable solution and can be used for the purpose described in this report.

\section{Summary}

Groundwater use in Mount Pleasant, SC, combined with irrigation pumpage at Kiawah Island, past use by the town of Summerville, and private industrial use in the Charleston, SC, area have created a large, regional cone of depression in the potentiometric surface of the Middendorf aquifer. In recent years, however, groundwater altitudes in the Middendorf aquifer have recovered in the Mount Pleasant area as a result of reduced withdrawals. From 2004 to 2008, Mount Pleasant Waterworks (MPW) has increased the use of surface water from 1.5 to $5.5 \mathrm{Mgal} / \mathrm{d}$. As a result of the reduced pumping, groundwater altitude in an observation well located in downtown Charleston has recovered $52 \mathrm{ft}$ from 2004 to 2008 . The recovery of groundwater altitudes in the area also is evident in Berkeley County where the long-term downward trend for an observation well has been eliminated due to reduced pumping.

In addition to reduced pumping from the Middendorf aquifer to alleviate the stress on this water source, MPW is investigating the potential of injecting highly treated reclaimed water into the Middendorf aquifer where it would be available for future use. To evaluate the effects of injecting reclaimed water into the Middendorf aquifer, an existing groundwaterflow model was updated to incorporate new water-use data and groundwater recharge estimates, and the model simulated three water-management scenarios to the year 2050. The groundwater-flow system of the Coastal Plain Physiographic Province of South Carolina and parts of Georgia and North Carolina was simulated using the USGS finite-difference code MODFLOW-2000. The update of the flow model included incorporation of 2005-2008 water-use data for wells located in the South Carolina Coastal Plain, and estimated net recharge data acquired since the previous investigation.

The update of the groundwater model required a slight recalibration because the simulated 2008 groundwater altitude for the downtown observation well was poor, and the predicted groundwater altitude at this well was to be used to make water-management decisions by MPW. The recalibration consisted of adjusting the simulated hydraulic properties of the Middendorf aquifer to allow a better fit of the 2005-2008 groundwater-level data for this well. This process used a technique of parameter estimation and allowed only 18 of the 434 previously documented model parameters to adjust during recalibration. The recalibrated parameters were the specific storage of the Middendorf aquifer and 17 horizontal hydraulic conductivity pilot points located in the Mount Pleasant model area. The strategy of limiting the number and areal location of parameters that were allowed to adjust during recalibration facilitated a better fit of the modeled data in the Mount Pleasant area while limiting the overall change to the calibrated model. Net changes to hydraulic conductivity pilot points ranged from -32 percent to 54 percent; however, the changes to horizontal hydraulic conductivity were not greater than an order of magnitude, and all were deemed within the confidence limits of aquifer test data. The calibrated specific storage value for the Middendorf aquifer changed from 0.0000025 to 0.0000029 per foot during recalibration, which is within reasonable limits for confined aquifers.

The updated groundwater-flow model was used to simulate three predictive water-management scenarios for 2009-2050 for the Middendorf aquifer in the Mount Pleasant, $\mathrm{SC}$, area. For the three scenarios, the total MPW pumping rate changed from the 2008 rate of $3.5 \mathrm{Mgal} / \mathrm{d}$ to 2023 rates of $6.65,8.50$, and $10.5 \mathrm{Mgal} / \mathrm{d}$ for the Base Case, Scenario 1, and Scenario 2, respectively. The Base Case simulation represents a non-injection estimate of 2050 groundwater levels for comparison purposes for the two injection scenarios. For Scenarios 1 and 2, the simulated injection of $3 \mathrm{Mgal} / \mathrm{d}$ begins in the year 2012 and continues through 2050.

Results from the Base Case simulation caused a general decline of about $90 \mathrm{ft}$ in the simulated potentiometric surface of the Middendorf aquifer in the Mount Pleasant area. The greatest changes in groundwater level occurred at the cells containing the production wells and produced a minimum simulated 2050 groundwater altitude of $348 \mathrm{ft}$ below the National Geodetic Vertical Datum of 1929. Simulated hydrographs for two area observation wells illustrate the gradual decline in groundwater levels with overall changes in water-level altitudes of -93 and -78 feet, respectively. Simulated groundwater altitudes at an imaginary well located in the MPW well field declined $75 \mathrm{ft}$ between 2004 and 2050. 
Scenario 1 simulates a combined moderate pumping rate of $8.5 \mathrm{Mgal} / \mathrm{d}$ from the MPW wells located in the Middendorf aquifer while injecting a total of $3 \mathrm{Mgal} / \mathrm{d}$ in three hypothetical wells located in the Mount Pleasant area. Simulated 2050 groundwater altitudes for this scenario declined to as low as $363 \mathrm{ft}$ below the National Geodetic Vertical Datum of 1929. Compared to the 2050 Base Case simulation, groundwater altitudes were between $15 \mathrm{ft}$ lower and $23 \mathrm{ft}$ higher at MPW production wells and between 41 and $77 \mathrm{ft} \mathrm{higher} \mathrm{at} \mathrm{the}$ injection wells. Simulated hydrographs for area observation wells show an initial recovery of groundwater altitudes in the Mount Pleasant area due to injection (2012-2014); however, as MPW pumping increases over time, recovery is eliminated and groundwater levels decline, but remain higher than the Base Case simulation. Although total MPW pumping is greater for Scenario 1 than the Base Case, simulated hydrographs for area wells are shallower in 2050 for Scenario 1. Injecting $3 \mathrm{Mgal} / \mathrm{d}$ of reclaimed water into the Middendorf aquifer more than compensates for the additional $1.85 \mathrm{Mgal} / \mathrm{d}$ pumped for Scenario 1. Although the general declines in the groundwater levels are still present for nearby observation wells, 2050 groundwater altitudes are between 9 and $23 \mathrm{ft}$ higher for Scenario 1 compared to the Base Case.

Scenario 2 simulates the maximum capacity pumping of $10.5 \mathrm{Mgal} / \mathrm{d}$ for the MPW network of production wells while injecting a total of $3 \mathrm{Mgal} / \mathrm{d}$ in three hypothetical wells located in the Mount Pleasant area. Simulated 2050 groundwater altitudes for this simulation declined to as low as $454 \mathrm{ft}$ below the National Geodetic Vertical Datum of 1929. Compared to the 2050 Base Case simulation, groundwater altitudes were between 14 and $106 \mathrm{ft}$ lower at MPW production wells and between 11 and $27 \mathrm{ft}$ higher at the injection wells. Simulated hydrographs for area observation wells show an initial recovery of groundwater altitudes in the Mount Pleasant area due to injection, with groundwater altitudes at well CHN-14 and the imaginary well between 5 and $37 \mathrm{ft}$ higher for the Scenario 2 simulation compared to the Base Case simulation from 2012 to 2022 . As the withdrawal rates are increased to $10.5 \mathrm{Mgal} / \mathrm{d}$, however, the hydrographs decline to altitudes between 2 and $38 \mathrm{ft}$ lower that those simulated for the Base Case.

Water budgets calculated for the model area immediately surrounding Mount Pleasant, SC, were calculated for 2011 and for 2050. The water budget for 2011 is equal for the Base Case, Scenario 1, and Scenario 2 because it represents the year prior to injection in Scenarios 1 and 2 and, therefore, the stresses for all three simulations are the same. The largest flow component in the 2011 water budget for the Mount Pleasant area is discharge to wells at a rate of 4,379,000 gal/d. Additionally, 299,000 gal/d flows laterally out of this zone into the Middendorf aquifer due to the regional hydraulic gradient. Flow into this zone consists predominantly of lateral flow within the Middendorf aquifer at 4,370,000 gal/d. Additionally, $164,000 \mathrm{gal} / \mathrm{d}$ is released into this zone from storage. Vertically, 92,200 gal/d flows down from the confining unit located above the Middendorf aquifer and 51,400 gal/d flows up from the confining unit below.
The largest flow component in the 2050 water budget for all three scenarios is discharge to wells in the Mount Pleasant area at rates between 7,079,000 and $10,929,000$ gallons of water per day. Flow into this zone consists mostly of lateral flow within the Middendorf aquifer for the Base Case $(6,957,000 \mathrm{gal} / \mathrm{d})$, and lateral flow $(5,975,000$ and $7,796,000 \mathrm{gal} / \mathrm{d})$ and injection through the hypothetical wells $(3,000,000 \mathrm{gal} / \mathrm{d})$ for Scenarios 1 and 2 . Between 86,800 and 116,000 gallons of water per day is released into this zone from storage. Between 175,000 and 319,000 gallons of water per day flows laterally out of this zone into adjacent areas of the Middendorf aquifer due to the regional hydraulic gradient. Finally, between 64,200 and 150,000 gallons of water per day flows vertically into this zone from confining units above and below the Middendorf aquifer.

Particle-tracking results indicate that reclaimed water injected into the Middendorf aquifer at the three hypothetical injection wells will move to the MPW production wells in 18 to 256 years. The times of travel and groundwater-flow paths were calculated for particles released at the injection wells using estimated aquifer porosities of 20 and 30 percent. Particle-tracking simulations were completed for Scenario 2 only and represent the worst-case (fastest travel time) situation for the two injection scenarios. Scenario 2 maximizes pumping from MPW wells and should, therefore, create the steepest head gradients and fastest transport times between injection and production wells. Times of travel varied from 18 to 179 years for a uniform aquifer porosity of 20 percent and between 25 to 256 years for a porosity of 30 percent.

\section{References Cited}

Aiken, G.R., and Kuniansky, E.L., eds., 2002, U.S. Geological Survey Artificial Recharge Workshop Proceedings, Sacramento, California, April 2-4, 2002: U.S. Geological Survey Open-File Report 02-89, 92 p.

Aucott, W.R., 1988, The predevelopment ground-water flow system and hydrologic characteristics of the Coastal Plain aquifers of South Carolina: U.S. Geological Survey WaterResources Investigations Report 86-4347, 66 p.

Aucott, W.R., 1996, Hydrology of the Southeastern Coastal Plain aquifer system in South Carolina and parts of Georgia and North Carolina: U.S. Geological Survey Professional Paper 1410-E, 83 p.

Aucott, W.R., and Newcome, Roy, Jr., 1986, Selected aquifer test information for the Coastal Plain aquifers of South Carolina: U.S. Geological Survey Water-Resources Investigations Report 86-4159, 30 p. 
Aucott, W.R., and Speiran, G.K., 1984, Water-level measurements for the Coastal Plain aquifers of South Carolina prior to development: U.S. Geological Survey Open-File Report 84-803, 36 p., 1 sheet.

Aucott, W.R., and Speiran, G.K., 1985, Potentiometric surfaces of the Coastal Plain aquifers of South Carolina prior to development: U.S. Geological Survey Water-Resources Investigations Report 84-4208, 5 sheets.

Campbell, B.G., and van Heeswijk, Marijke, 1996, Groundwater hydrology, historical water use, and simulated ground-water flow in Cretaceous-age Coastal Plain aquifers near Charleston and Florence, South Carolina: U.S. Geological Survey Water-Resources Investigations Report 96-4050, 100 p.

Doherty, John, 2003, Ground water model calibration using pilot points and regularization: Ground Water, v. 41, no. 2, p. $170-177$.

Doherty, John, 2005, PEST, model independent parameter estimation user manual (5th ed.): Brisbane, Australia, Watermark Numerical Computing, $336 \mathrm{p}$.

Harbaugh, A.W., Banta, E.R., Hill, M.C., and McDonald, M.G., 2000, MODFLOW-2000, The U.S. Geological Survey modular ground-water model - User guide to modularization concepts and the ground-water flow process: U.S. Geological Survey Open-File Report 00-92, 121 p.

Heath, R.C., 1983, Basic ground-water hydrology: U.S. Geological Survey Water-Supply Paper 2220, 84 p.

Hockensmith, B.L., 2008, Potentiometric surface of the Middendorf aquifer in South Carolina-November 2004: South Carolina Department of Natural Resources, Land, Water and Conservation Division, Water Resources Report 46, 16 p.

Lee, R.W., DeJarnette, S.S., and Barker, R.A., 1986, Distribution and altitude of the top of saline ground water in the Southeastern Coastal Plain: U.S. Geological Survey WaterResources Investigations Report 85-4109, 1 sheet.

Newcome, Roy, Jr., 1993, Pumping tests of the Coastal Plain aquifers in South Carolina with a discussion of aquifer and well characteristics: South Carolina Water Resources Commission Report 174, 52 p.

Newcome, Roy, Jr., 2000, Results of pumping test of the Coastal Plain of South Carolina: State of South Carolina Department of Natural Resources Open-File Report 5, 26 p.
Oregon Climate Service, 2007, Average annual precipitation [State]: Corvallis, Oregon, Oregon Climate Service, accessed May 15, 2007, at http://www.ocs.orst.edu/pub/ maps/Precipitation/Total/States/.

O’Reilly, R.M., 1998, Hydrogeology and simulation of the effects of reclaimed-water application in West Orange and Southeast Lake Counties, Florida: U.S. Geological Survey Water-Resources Investigations Report 97-4199, 91 p.

Payne, D.F., Rumman, M.A., and Clarke, J.S., 2005, Simulation of ground-water flow in coastal Georgia and adjacent parts of South Carolina and Florida - Predevelopment, 1980, and 2000: U.S. Geological Survey Scientific Investigations Report 2005-5089, $91 \mathrm{p}$.

Petkewich, M.D., and Campbell, B.G., 2007, Hydrogeology and simulation of ground-water flow near Mount Pleasant, South Carolina—Predevelopment, 2004, and predicted scenarios for 2030: U.S. Geological Survey Scientific Investigations Report 2007-5126, 79 p.

Pollock, D.W., 1994, User's guide for MODPATH/MODPATH-PLOT, version 3-A particle tracking post-processing package for MODFLOW, the U.S. Geological Survey finite-difference ground-water flow model: U.S. Geological Survey Open-File Report 94-464, 6 chapters.

Southeast Regional Climatic Data Center, 2009a, Aiken 4 NE, South Carolina (380074), Period of record monthly climate summary, accessed April 1, 2009, at http://www.sercc.com/ cgi-bin/sercc/cliMAIN.pl?sc0074.

Southeast Regional Climatic Data Center, 2009b, Cheraw, South Carolina (381588), Period of record monthly climate summary, accessed April 1, 2009, at http://www.sercc.com/ cgi-bin/sercc/cliMAIN.pl?sc1588.

Southeast Regional Climatic Data Center, 2009c, Columbia Univ of SC, South Carolina (381944), Period of record monthly climate summary, accessed April 1, 2009, at http://www.sercc.com/cgi-bin/sercc/cliMAIN.pl?sc1944.

Temples, T.J., and Waddell, M.G., 1996, Application of petroleum geophysical well logging and sampling techniques for evaluating aquifer characteristics: Ground Water, v. 34, no. 3 , p. 523-531.

U.S. Environmental Protection Agency, 2004, Guidelines for water reuse: U.S. Environmental Protection Agency Document EPA/625/R-04/108, 478 p. 
U.S. Geological Survey, 2009a, Ground-water levels for South Carolina; National Water Information System: Web Interface, accessed March 24, 2009, at http:// nwis.waterdata.usgs.gov/sc/nwis/gwlevels?site no $=325136079504200 \&$ agency_cd $=$ USGS\&format $=\mathrm{html}$.

U.S. Geological Survey, 2009b, USGS Groundwater data for South Carolina, accessed March 25, 2009, at http://waterdata.usgs.gov/ sc/nwis/dv?cb_72019=on\&format $=$ rdb\&begin date $=1990-03-04 \&$ end_date $=2008-12-31 \&$ site no $=324729079472001 \&$ referred_module $=$ gw.
U.S. Geological Survey, 2009c, Reclaimed wastewaterUsing treated wastewater for other purposes; Water Science for Schools, accessed March 27, 2009, at http://ga.water. usgs.gov/edu/wwreclaimed.html.

U.S. Geological Survey, 2009d, USGS Groundwater data for South Carolina, accessed March 25, 2009, at http://waterdata.usgs.gov/ sc/nwis/dv?cb $72019=$ on\&format $=$ rdb\&begin date $=1989-10-04 \&$ end date $=2008-12-31 \&$ site no $=331022080021801 \&$ referred_module $=$ gw.

For additional information regarding this publication, contact: USGS South Carolina Water Science Center 720 Gracern Road, Suite 129

Columbia, South Carolina 29210-7651

phone: 803-750-6100

http://sc.water.usgs.gov/

Edit and layout by Kay E. Hedrick

Graphics by Bonnie J. Turcott and Jeffrey L. Corbett 


\section{总}

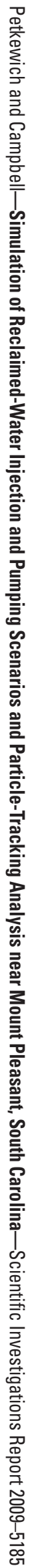

